\title{
Evidence, Community Protection AND LIBERTY IN AUSTRALIAN POST- SENTENCE PROTECTION LEgISLATION
}

\author{
GeOfFREY SMITH*
}

This article addresses a number of issues regarding post-sentence detention order regimes in the context of an analysis of a collection of publicly available judgments made under the Dangerous Prisoners (Sexual Offenders) Act 2003 (Qld). The article raises concerns regarding the accuracy of the psychiatric evidence presented to the court. However, it suggests that the way in which the psychiatrists conduct their prisoner assessments, and the way in which judges have applied the main rules of expert evidence, have combined to ensure that the potential for unjust outcomes has been minimised. The article also suggests that judges have struck a fine balance between community protection and prisoner liberty, by in most cases making supervision orders which allow prisoners to be released into the community under strict conditions, rather than making detention orders. As no prisoner released under a supervision order is known to have committed a further sex offence, it is the conclusion of this article that the judges' approach to cases under the Dangerous Prisoners (Sexual Offenders) Act 2003 (Qld) has been highly successful, and may represent a solution to the serious problem of recidivist sex offenders within the community.

\section{INTRODUCTION}

Nothing seems to incite anger within the community quite like the prospective release from prison of a sex offender, particularly one who has taken children as his victims. His prison term is nearly always considered unjustly lenient, and his release is more often than not viewed by the

\footnotetext{
* BA, LLB (Hons), articled clerk at Slater \& Gordon Lawyers. This article was initially submitted in completion of the thesis component of the Honours program at La Trobe University. The author wishes to acknowledge Dr Steven Tudor for his invaluable comments on drafts of this article. The views expressed in this article are the author's and do not necessarily reflect those of Slater \& Gordon Lawyers.
} 
community as merely an invitation for him to continue his criminal course of conduct. In recent years, media scrutiny of sex offender cases, and public hysteria surrounding predatory sex offenders within the community, has increased to the extent that, according to criminologist $\mathrm{Dr}$ Stephen Smallbone, 'there's no doubt at all that we are in the midst of a so-called moral panic, particularly with respect to sexual offences'.

In response to the growing public outcry, governments across Australia have enacted an increasing amount of legislation aimed at protecting the community from the threat of sex offenders. ${ }^{2}$ Importantly, the primary focus of this legislation has been on preventing recidivism through initiatives such as sex offender registers, rather than trying to reduce the number of primary offences that are committed. But, in trying to design measures to ensure public safety, policy makers have faced a serious dilemma. As outlined by $\mathrm{Dr}$ Karen Gelb,

[a]t the heart of the dilemma is a balancing exercise - between the community's right to safety and ... to be protected from convicted offenders who are ... at high-risk of committing further serious crimes, and the rights of offenders who have served their sentence to be free from further confinement... ${ }^{3}$

In 2003, the Queensland Parliament appeared to tip this balance away from the long-held presumption in favour of an offender's right to unfettered liberty following the expiration of his sentence. The result was perhaps the most radical sex offender legislation ever to be passed in this country, the Dangerous Prisoners (Sexual Offenders) Act 2003 (Qld) (DP(SO)A).

In order to 'ensure adequate protection of the community', ${ }^{4}$ the $D P(S O) A$ empowers the State's Attorney-General to apply to the Supreme Court for an order enabling the indefinite detention of a prisoner who is within six months

\footnotetext{
${ }^{1}$ ABC Television, 'Media Frenzy Raises Questions about Rehabilitation of Sex Offenders', The 7.30 Report, 2 February 2005

$<$ http://www.abc.net.au/7.30/content/2005/s1294801.htm> at 11 April 2007.

${ }^{2}$ See, eg, Criminal Law (Sex Offenders Reporting) Act 1997 (Qld); Child Protection (Offenders Registration) Act 2000 (NSW); Sex Offenders Registration Act 2004 (Vic); Crimes (Child Sex Offenders) Act 2005 (ACT); Child Sex Offenders Registration Act 2006 (SA); Community Protection (Offender Reporting) Regulations 2006 (Tas).

${ }^{3}$ Karen Gelb, 'Recidivism of Sex Offenders' (Research Paper, Sentencing Advisory Council, 2007) 1.

${ }^{4} D P(S O) A$ s $3(\mathrm{a})$.
} 
of serving the full term of his imprisonment for a serious sexual offence. ${ }^{5}$ For the purposes of the Act, a serious sexual offence is defined in the Schedule as one of a sexual nature, involving violence or against children. ${ }^{6}$ Section 13 of the $D P(S O) A$ provides that, should the court be satisfied that the prisoner poses a 'serious danger to the community', it may make an indefinite detention order for the care, control or treatment of the prisoner, or a supervision order under which the prisoner is released subject to certain conditions. ${ }^{8}$ These conditions, contained in section 16 , require that the prisoner-

(a) report to a corrective services officer at the place, and within the time, stated in the order and advise the officer of the prisoner's current name and address; and

(b) report to, and receive visits from, a corrective services officer as directed by the judicial authority; and

(c) notify a corrective services officer of every change of the prisoner's name, place of residence or employment at least 2 business days before the change happens; and

(d) be under the supervision of a corrective services officer; and

(e) not leave or stay out of Queensland without the permission of a corrective services officer; and

(f) not commit an offence of a sexual nature during the period of the order. ${ }^{9}$

The court may also place any additional conditions upon the prisoner that it feels are necessary to ensure that the prisoner does not re-offend upon release. $^{10}$

In deciding whether the prisoner poses a serious danger to the community, the court must determine whether there is an 'unacceptable risk' of the prisoner committing a serious sexual offence should they be released from custody without supervision. ${ }^{11}$

\footnotetext{
${ }^{5} D P(S O) A$ s 5.

${ }^{6} \mathrm{DP}(\mathrm{SO}) \mathrm{A}$ sch.

${ }^{7} D P(S O) A$ s $13(1)$.

${ }^{8} D P(S O) A$ s $13(5)$.

${ }^{9} D P(S O) A$ s $16(1)$.

${ }^{10} D P(S O) A$ s $16(2)$.

${ }^{11} D P(S O) A$ s 13(2).
} 
By introducing post-sentence protection orders to the repertoire of judicial powers, the $D P(S O) A$ has required judges to adopt a wholly new style of decision making, one seemingly at odds with judicial traditions in this country. True it is that the "ultimate justification for criminal sanctions is the protection of society from ... conduct which the law proscribes, ${ }^{12}$ and sentencing legislation includes protection of the community from the offender as a legitimate purpose of sentencing. ${ }^{13}$ However, Australian judges have not historically been empowered to imprison a person unless that person has been convicted of a criminal offence, regardless of the danger they may pose to society. Even those most serious sentencing options, such as indefinite detention, which are applied to those with involved criminal histories and for which community protection is of paramount concern, are connected to a contemporary offence. In contrast to this, the $D P(S O) A$ asks judges to consider detaining prisoners, not so that they may be punished further, but for the sole purpose of protecting the community, and based entirely upon an assessment of their likelihood of future re-offending.

\section{A Purpose and Outline}

The purpose of this article is to investigate the way in which judges of the Queensland Supreme Court and Court of Appeal have responded to the task of making decisions of this nature, and to identify any significant trends in their decision making.

While not the focus of this article, it is important to note that there has been significant controversy surrounding the $D P(S O) A$ and the increasing spread of post-sentence protection order regimes generally.

This is for a number of reasons, the first of which is that the $D P(S O) A$ is seen by some as an example of an increasing trend within Australian jurisdictions to impose sanctions against people not because of what they have done, but because of who they are, and what they might do in the future. Such policies are often justified as being integral to the protection of the community from its most dangerous elements. However, there has been concern that the $D P(S O) A$ and other preventive measures are merely an attempt by governments to capitalise politically on the heightened state of fear and

\footnotetext{
${ }^{12}$ Channon v R (1978) 33 FLR 433, 437.

${ }^{13}$ See, eg, Sentencing Act 1991 (Vic) s 5(1)(e).
} 
uncertainty with regard to issues of security that has existed within Australia in recent times. ${ }^{14}$

Secondly, the political climate described above has resulted in a legislative backlash against those fundamental legal principles that have for a long time acted as a bulwark for individuals against the excesses of government. Despite the High Court's opinion to the contrary, there has been support for the view that the $D P(S O) A$ offends a number of such principles, including the rule of law and the principle against double punishment. ${ }^{15}$

Thirdly, it has been argued that the failure of the $D P(S O) A$ to uphold the principle of double punishment is in breach of international law, insofar as it contravenes the International Covenant on Civil and Political Rights' provision against double jeopardy. ${ }^{16}$ This is not surprising, considering the tendency of Australian governments, particularly during the last decade, to disregard international institutions and instruments when formulating policy.

Be it to enhance community protection or for more cynical reasons, the New South Wales and Western Australian governments both rushed to enact postsentence protection order legislation of their own soon after the High Court's declaration of the $D P(S O) A$ 's constitutional validity. ${ }^{17}$ However, whatever the motives of government, Professor Bernadette McSherry maintains that the reason why legislation such as the $D P(S O) A$ is so popular within the community is that it caters to people's tendency to 'to focus on the worst-case scenarios rather than the probability of such scenarios occurring'. ${ }^{18}$

\footnotetext{
${ }^{14}$ See, eg, Bernadette McSherry, 'Sex, Drugs and 'Evil' Souls: The Growing Reliance on Preventive Detention Regimes, (2006) 32 Monash University Law Review 237.

${ }^{15}$ See, eg, Patrick Keyzer, Cathy Pereira, Stephen Southwood QC, 'Pre-emptive Imprisonment for Dangerousness in Queensland under the Dangerous Prisoners (Sexual Offenders) Act 2003: The Constitutional Issues, (2004) 11 Psychiatry, Psychology and Law 244; Bernadette McSherry, 'Indefinite and Preventive Detention Legislation: From Caution to an Open Door' (2005) 29 Criminal Law Journal 94.

${ }^{16}$ Patrick Keyzer and Sam Blay, 'Double Punishment? Preventive Detention Schemes under Australian Legislation and their Consistency with International Law: The Fardon Communication' (2006) 7 Melbourne Journal of International Law 407.

${ }^{17}$ Dangerous Sexual Offenders Act 2006 (WA); Crimes (Serious Offenders) Act 2006 (NSW).

${ }^{18}$ McSherry, above n 14, 267.
} 
For now, the policy decision as to whether there should be such an Act has been decided by the Queensland Parliament, and this article will not rehearse the general policy debates behind the legislation's desirability. Nonetheless, developing an understanding of how the Act is actually performing and the outcomes being achieved through its operation may yield a better sense of its true moral character. In order to achieve this, the article is structured in accordance with the following outline:

Part II of the article explains the relevant features of the $D P(S O) A$, its constitutionality, and the way in which post-sentence protection order legislation has evolved since its introduction;

Part III analyses judicial treatment of expert psychiatric evidence under the $D P(S O) A$, which is of particular importance to the operation of the Act;

Part IV outlines how the judiciary has sought to resolve the inevitable conflict between the competing imperatives of community protection and prisoner liberty that arises under the Act;

Finally, Part V underlines some of the lessons to be learnt from the Queensland experience, with reference to the recommendations of the Victorian Sentencing Advisory Council, which has recently recommended against the introduction of post-sentence preventive detention in that State. ${ }^{19}$

\section{B Methodology}

In preparation for this article, all publicly available judgments made under the $D P(S O) A$ between the Act's introduction in 2003, and 12 July 2007, were analysed. ${ }^{20}$ In total, 54 judgments from a variety of proceedings heard under the Act were located, including originating applications, determinations of orders, annual detention order reviews, as well as appeals. These judgments are listed in the Appendix. The collection appears not to be exhaustive, as the judgments often make reference to past or future hearings for which no record could be located. Nonetheless, the collection was sufficient for the purposes of identifying trends in judicial decision making, the results of which have not, to the knowledge of the author, been published previously.

\footnotetext{
${ }^{19}$ Sentencing Advisory Council, High-Risk Offenders: Post-Sentence Supervision and Detention, Final Report (2007).

${ }^{20}$ The online databases utilised for this task were CaseBase (a LexisNexis database), and Austlii (http://www.austlii.edu.au/). The author also spoke to Len Brown of the Queensland Department of Justice by telephone on 12 July 2007.
} 
In the context of the debate regarding the efficacy of post-sentence protection order regimes, this analysis is an important exercise, as Western Australia and New South Wales have already followed Queensland's lead and enacted legislation similar in character to the $D P(S O) A$. Considering the political traction governments generally achieve through 'tough on crime' policies, it is not unreasonable to suggest that such regimes will be expanded in their application to include offences beyond those that are sexual in nature.

\section{Results}

As will be seen, this article indicates that Queensland judges have been somewhat reluctant to grant indefinite detention orders, having made only eight within the period of analysis. On the other hand, 30 supervision orders had been granted. ${ }^{21}$ However, the judges' use of expert psychiatric evidence to identify those environmental factors and risk behaviours that are most likely to result in a prisoner re-offending upon release, in order to develop specifically targeted supervision orders, has proved highly successful. In fact, while supervision orders have been breached on a number of occasions, at the time that this article was written, no prisoner released under a supervision order had been known to commit a further serious sexual offence. By not granting a large number of detention orders, it is certainly possible that the judges have not acted in the manner contemplated by the Queensland Government when it introduced the $D P(S O) A$, but it could be that judges have discovered a way to reduce the harmful impact of recidivist sex offenders upon the community. What is remarkable is that they have done so while at the same time minimising the seemingly inevitable erosion of one of the fundamental civil liberties enjoyed by individuals in this country.

\section{THE $D P(S O) A$, ITS CONSTITUTIONALITY, AND THE EVOLUTION OF AUSTRALIAN POST-SENTENCE Preventive Detention LegisLation}

\section{A Relevant Features of the DP(SO)A}

It is first necessary to outline those features of the $D P(S O) A$ relevant to this article.

\footnotetext{
${ }^{21}$ This information was provided by Len Brown of the Queensland Department of Justice during the telephone interview on 12 July 2007.
} 
When deciding whether to make either a detention order or supervision order, the court's decision must be based on the reception of acceptable, cogent evidence. ${ }^{22}$ The court must also be satisfied, to a high degree of probability, that its decision is justified. ${ }^{23}$ This standard of proof sits between the higher criminal standard of beyond reasonable doubt, and the lower civil standard of a balance of probabilities. Indeed, the $D P(S O) A$ does not explicitly specify whether proceedings under the act are criminal or civil in nature.

Since the decision in Thompson $v R^{24}$ the imposition of an indefinite prison sentence for a criminal offence has only been sanctioned following the reception of 'adequate and complete' 25 psychological reports, and the $D P(S O) A$ appears to have been drafted in consideration of this rule. Should the court be satisfied after a preliminary hearing that there are reasonable grounds for believing that the prisoner would represent a serious danger to the community in the absence of a detention or supervision order, it may make a risk assessment order. ${ }^{26}$ Such an order authorises the examination of the prisoner by two psychiatrists, ${ }^{27}$ and each must submit a report indicating their 'assessment of the level of risk that the prisoner will commit another serious sexual offence - i) if released from custody; or, ii) if released from custody without a supervision order being made'. ${ }^{28}$ The report must also contain the reasons for the psychiatrist's assessment. ${ }^{29}$

To assist the court in making its final determination, the $D P(S O) A$ outlines in section 13(4) the evidence to which the court must have regard. This includes the risk assessment reports prepared by the two psychiatrists, as well as the extent to which the prisoner co-operated with the assessment process. ${ }^{30}$ The court must also have regard to any other medical, psychiatric, psychological or other assessment relating to the prisoner. ${ }^{31}$ Furthermore, the court must consider any evidence of the prisoner's propensity to commit serious sexual offences in the future, ${ }^{32}$ whether a pattern exists in the prisoner's offending

\footnotetext{
${ }^{22} D P(S O) A$ s $13(3)(\mathrm{a})$.

${ }^{23} D P(S O) A$ s $13(3)(\mathrm{b})$.

${ }^{24}$ (1999) 165 ALR 219.

${ }^{25}$ Ibid 224 (Kirby J).

${ }^{26} D P(S O) A$ s $8(2)(a)$.

${ }^{27} \mathrm{DP}(\mathrm{SO}) \mathrm{A}$ s 9.

${ }^{28} D P(S O) A$ s $11(2)(\mathrm{a})$.

${ }^{29} D P(S O) A$ s $11(2)(\mathrm{b})$.

${ }^{30} D P(S O) A$ s $13(4)(\mathrm{a})$.

${ }^{31} D P(S O) A$ s $13(4)(\mathrm{b})$.

${ }^{32} D P(S O) A$ s $13(4)(\mathrm{c})$.
} 
behaviour, ${ }^{33}$ the prisoner's efforts to address the causes of their offending and their attendance at rehabilitation programs, ${ }^{34}$ whether their attendance at rehabilitation has had a positive effect upon the prisoner, ${ }^{35}$ the prisoner's antecedents and criminal history, ${ }^{36}$ as well as any other relevant matter. ${ }^{37}$

Regulating this evidence received under section 13(4) are the 'ordinary rules of evidence ... [that] apply to evidence given or called' in proceedings under the Act. $^{38}$

The 'paramount consideration' for the court at all times during its deliberations must be the first object of the legislation, which, as stated above, is to ensure the adequate protection of the community. ${ }^{39}$ Although its second object is to facilitate the rehabilitation of the prisoner, ${ }^{40}$ and one of the purposes of a detention order is to allow a prisoner to receive treatment for his behaviours, ${ }^{41}$ the $D P(S O) A$ does not expressly require that the interests of the prisoner be taken into account at any stage during the application process. Should the court order that a prisoner be detained beyond the expiration of their sentence, it must review the order annually, ${ }^{42}$ or upon application with leave by the prisoner. ${ }^{43}$ This is the only measure in place to safeguard the prisoner's access to liberty should a detention order be made against them.

\section{B Fardon v Attorney-General (QId) and the Constitutionality of the DP(SO)A}

The High Court declared the $D P(S O) A$ constitutionally valid in Fardon $v$ Attorney-General (Qld), ${ }^{44}$ deciding that the Act did not empower the judges of the Queensland Supreme Court to perform a function incompatible with that court's status as one vested with federal judicial power under Chapter III of the Australian Constitution. ${ }^{45}$

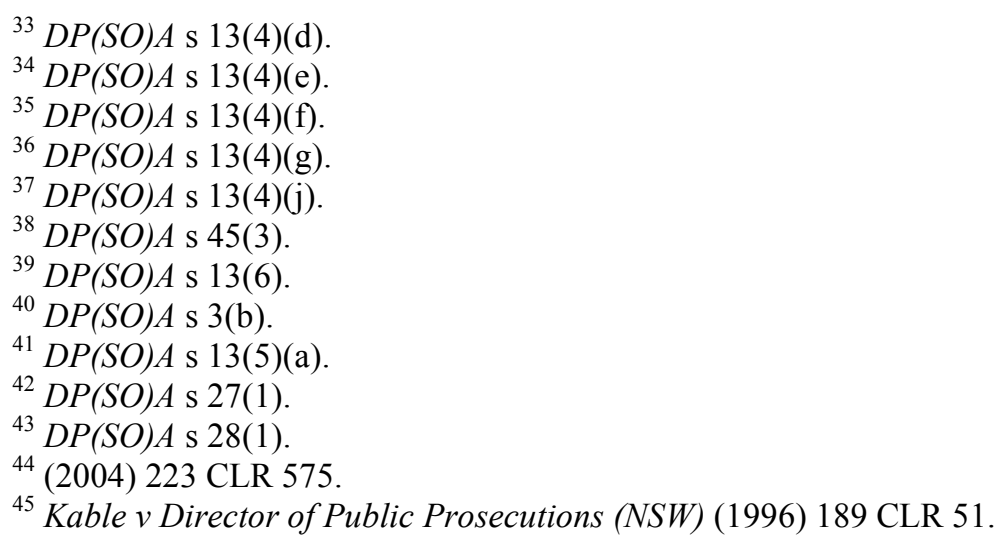


It is a matter of concern that the judges failed to address, among other things, the $D P(S O) A$ 's apparent inconsistency with precedent regarding the need for proportionate sentencing. However, their decision is, at least for the time being, final, and it is not the purpose of this outline to evaluate in any great detail the remarks of the majority judges. Therefore, merely a brief outline of those parts of the decision relevant to this article's discussion of the Act's operation is provided here.

The system established by the $D P(S O) A$ controversially assumes that psychiatrists can predict with relative precision and certainty a prisoner's likelihood of re-offending. Chief Justice Gleeson dismissed concerns regarding the accuracy of such predictions, stating, 'No doubt, predictions of future danger may be unreliable, but as the case in Veen shows, they may also be right ${ }^{46}$ Justice Gummow referred to McHugh J's acknowledgment in Kable v Director of Public Prosecutions (NSW) that there are difficulties associated with the prediction of future dangerousness. However, he contended that, in the case of the $D P(S O) A$, these difficulties are overcome by the court's mandatory consideration of psychiatric reports outlining the prisoner's risk of further offending, the prisoner's offending patterns, and the prisoner's participation in rehabilitation programs. ${ }^{47}$ Only Kirby J, the sole dissenting judge, used the $D P(S O) A$ 's dependence upon 'notoriously unreliable ${ }^{48}$ predictions of criminal dangerousness as a basis for holding that the Act requires the court to perform a function repugnant to the judicial process.

Regarding the $D P(S O) A$ 's procedures, of particular note was the opinion of all of the majority judges that the $D P(S O) A$ confers upon the court 'a substantial discretion ${ }^{49}$ whether or not to make an order, should it determine the relevant standard of proof to have been met. In the event that the court does decide to make an order, it is presented with another discretionary decision, being whether to impose a supervision order or a detention order, and what the particulars thereof will be ${ }^{50}$ Chief Justice Gleeson, McHugh J, and Callinan and Heydon JJ, also all confirmed that the rules of evidence are to apply to proceedings under the Act. ${ }^{51}$ These two points, as well as the fact

\footnotetext{
${ }^{46}$ Fardon v Attorney-General (Qld) (2004) 223 CLR 575, 589.

${ }^{47}$ Ibid 616-617.

${ }^{48}$ Ibid 639.

${ }^{49}$ Ibid 592 (Gleeson J).

${ }^{50}$ Ibid.

${ }^{51}$ Ibid 585, 588 (Gleeson CJ); 592, 597, 602 (McHugh J); 656, 657 (Callinan and Heydon JJ).
} 
that the onus of proof lies with the Attorney-General, ${ }^{52}$ that annual reviews are undertaken into all detention orders, ${ }^{53}$ and that prisoners subject to orders are granted a right of appeal ${ }^{54}$ were all reasons why it was decided by the majority that the judicial function established by the $D P(S O) A$ is consistent with that traditionally performed by the judiciary.

Although Gleeson CJ acknowledged that the $D P(S O) A$ raises '[s]ubstantial questions of civil liberty, ${ }^{55}$ he, along with the other majority justices, refused to entertain the notion that these questions were pertinent to the proceedings. This was because the case was 'not concerned with those wider issues'. According to Gleeson CJ, the politically controversial nature of the decisions that the Queensland Supreme Court is asked to make under the $D P(S O) A$ does not render the Act inherently incompatible with the judicial process. ${ }^{57}$ Justice McHugh concurred, arguing that legislation does not undermine the institutional integrity of the judiciary merely because it is offensive to the libertarian worldview, and should not be invalidated upon this basis. ${ }^{58} \mathrm{He}$, along with Callinan and Heydon JJ, also determined the object of the Act to be the protection of the community, and not the punishment of the prisoner, offering this as another characteristic in favour of the Act's constitutionality. ${ }^{59}$ On the other hand, Kirby $\mathrm{J}$ was so concerned by the character of the legislation that he asked whether Australians have 'debased liberty so far that deprivation of liberty, for yearly intervals, confined in a prison cell, is now regarded as immaterial or insignificant'. ${ }^{60}$

\section{Post-Sentence Detention and Supervision Legislation in Other Australian Jurisdictions}

With the $D P(S O) A$ constitutionally validated, Western Australia (WA) and New South Wales (NSW) followed Queensland's lead and enacted laws which provide for the post-sentence detention and supervision of certain classes of offenders. Unsurprisingly, the WA and NSW Acts are materially very similar to the $D P(S O) A$, in many instances borrowing its exact language. However, legislative evolution is to be expected, and it is in the offences for

\footnotetext{
${ }^{52}$ Ibid 592 (Gleeson CJ); 602 (McHugh J); 656, 657 (Callinan and Heydon JJ).

${ }^{53}$ Ibid 619-621 (Gummow J); 654, 658 (Callinan and Heydon JJ).

${ }^{54}$ Ibid 592 (Gleeson CJ).

${ }^{55}$ Ibid 586.

${ }^{56}$ Ibid.

${ }^{57}$ Ibid 592-593.

${ }^{58}$ Ibid 600-601.

${ }^{59}$ Ibid 596-597 (McHugh J); 694 (Callinan and Heydon JJ).

${ }^{60}$ Ibid 596-597 (McHugh J); 653-655 (Callinan and Heydon JJ).
} 
which a prisoner may be eligible for a post-sentence protection order application that the first notable deviations from the Queensland model can be identified.

\section{$1 \quad$ Western Australia}

Like the $D P(S O) A$, the Dangerous Sexual Offenders Act 2006 (WA) (DSOA) applies to offenders serving terms of imprisonment for a serious sexual offence. ${ }^{61}$ Under WA law, a serious sexual offence is defined as being one for which the maximum penalty that may be imposed is at least seven years. ${ }^{62}$ These include sexual offences against children under both the Criminal Code $1913^{63}$ and Prostitution Act 2000 (WA), ${ }^{64}$ and other sexual offences contained within Division XXXI of the Criminal Code 1913, including offences involving penetration without consent, ${ }^{65}$ offences involving coercion $^{66}$ or servitude, ${ }^{67}$ and offences against people who are mentally impaired..$^{68}$ The $D S O A$ is therefore broader in application than the $D P(S O) A$, as it includes amongst its eligible offences a number of sexual offences against adults where violence is not an element.

\section{$2 \quad$ New South Wales}

In enacting the Crimes (Serious Sex Offenders) Act 2006 (NSW) (C(SSO)A), the NSW Parliament has adopted a scheme broader still, extending the criteria of eligibility beyond those prisoners serving terms of imprisonment for serious sexual offences, to also include those prisoners who are serving terms for offences of a sexual nature. ${ }^{69}$ Offences of a sexual nature include, but are not limited to, offences involving child prostitution and pornography, which carry prison terms of 7 to 14 years, ${ }^{70}$ as well as acts of indecency and indecent assault without aggravation, which carry prison terms of 18 months to 5 years. ${ }^{71}$ It is therefore possible under the $C(S S O) A$ to be the subject of a

\footnotetext{
${ }^{61}$ DSOA s 8(1).

${ }^{62}$ Evidence Act 1906 (WA) s 106A.

${ }^{63}$ Criminal Code 1913 ss 320-322.

${ }^{64}$ Prostitution Act 2000 (WA) ss 16-s18.

${ }^{65}$ Criminal Code 1913 (WA) ss 325-326.

${ }^{66}$ Criminal Code 1913 (WA) ss 327-328.

${ }^{67}$ Criminal Code 1913 (WA) ss 331B-331C.

${ }^{68}$ Criminal Code 1913 (WA) s 330.

${ }^{69} \mathrm{C}(\mathrm{SSO}) \mathrm{A}$ s 6(1).

${ }^{70}$ Crimes Act 1900 (NSW) ss 91D-91H.

${ }^{71}$ Crimes Act 1900 (NSW) ss 61L, 61N.
} 
detention order, even if imprisoned for non-violent contact offences or noncontact offences of a sexual nature against adults.

In his second reading speech, the Hon Tony Kelly, NSW Minister for Justice, stated that the $C(S S O) A$

relates to a handful of high-risk, hard-core offenders who have not made any attempt to rehabilitate whilst in prison. These offenders make up a very small percentage of the prison population, yet their behaviour poses a very real threat to the public. ${ }^{72}$

He stated further that the Act's definitions of what constitutes a 'serious sexual offence' and 'offence of a sexual nature' will 'capture the worst sexual recidivists in our system'. ${ }^{73}$ Research suggests that non-contact sex offenders do have high rates of recidivism, but also that it is generally unlikely that their offending will escalate in character towards serious contact sex offences. $^{74}$ It is therefore debatable whether the threat these offenders pose to the public is serious enough to warrant the imposition of a measure as extreme as a post-sentence indefinite detention order.

\section{$3 \quad$ Victoria}

Victoria's post-sentence protection order regime at this point consists of the Serious Sex Offenders Monitoring Act 2005 (Vic) (SSOMA), which includes only the authorisation to make supervision orders. However, at the AttorneyGeneral's request, the Victorian Sentencing Advisory Council (VSAC) recently considered whether the State should introduce post-sentence detention orders as well. ${ }^{75}$ Under the model considered by the VSAC in its Discussion Paper, Victorian prisoners would be eligible for post-sentence detention if they are serving a custodial sentence for any sexual offence against either a child or an adult. The model also included two further options, the first of which excluded all non-contact offences carrying a

\footnotetext{
${ }^{72}$ New South Wales, Second Reading: Crimes (Serious Sex Offenders) Bill, Legislative Council, 30 March 2006, 21801 (Tony Kelly, Minister for Justice).

${ }^{73}$ Ibid.

${ }^{74}$ Gary J D MacPherson, 'Predicting Escalation in Sexually Violent Recidivism: Use of the SVR-20 and PCL:SV to Predict Outcome with Non-contact Recidivists and Contact Recidivists' (2003) 14 The Journal of Forensic Psychiatry and Psychology 615,616 .

${ }^{75}$ Sentencing Advisory Council, High Risk Offenders: Post-Sentence Supervision and Detention, Discussion and Options Paper (2007); Sentencing Advisory Council, above n 19.
} 
maximum penalty of less than 5 years, and the second of which included homicides with a sexual element or motivation. ${ }^{76}$ In comparative terms, replication of this model in legislation would mean that the Victorian scheme would not appear to be as broad in its application as the NSW Act, but still broader than the $D P(S O) A$.

In its final report, the VSAC rejected the model considered in the Discussion Paper, and recommended against the introduction of post-sentence detention, suggesting that Victoria would be better served by reforms to the system of post-sentence supervision orders established by the SSOMA.$^{77}$ This was not a unanimous view, but one held by a majority of VSAC members. The reason why the VSAC decided against recommending the introduction of postsentence detention orders was that it believed any potential benefits to be gained by such a measure would be outweighed by its dangers. ${ }^{78}$ In particular, the VSAC was concerned about the accuracy of the predictions of risk upon which the orders would be based, and was sceptical of the effectiveness of post-sentence detention schemes in reducing sex offending, citing the lack of available research in this area. ${ }^{79}$ The VSAC also argued that post-sentence detention schemes have the potential to 'unjustifiably ... limit human rights and due process, ${ }^{80}$ and maintained that there are more costeffective ways to address the risk sex offenders pose to the community. ${ }^{81}$

Although the VSAC decided not to support the introduction of post-sentence detention legislation, it made numerous recommendations as to how such a scheme should be structured if one were to be introduced. In response to the VSAC's final report, the Victorian Government has confirmed that it intends to continue with its plans to enact a post-sentence detention order regime. In the meantime, the Government has recently broadened the application of the SSOMA to include sex offenders whose crimes were committed against adults, but it still intends to introduce the Serious Sex Offenders (Detention and Supervision) Bill at some point during $2008 .^{82}$

\footnotetext{
${ }^{76}$ Sentencing Advisory Council, High Risk Offenders: Post-Sentence Supervision and Detention, Discussion and Options Paper (2007) 115.

${ }^{77}$ Sentencing Advisory Council, above n 19.

${ }^{78}$ Ibid 64.

${ }^{79}$ Ibid.

${ }^{80}$ Ibid.

${ }^{81}$ Ibid.

${ }^{82}$ Premier of Victoria, 'Extended Supervision Orders to Cover Offenders with Adult Victims', (Press Release, 15 April 2008)

$<$ http://www.premier.vic.gov.au/newsroom/extended-supervision-orders-to-coveroffenders-with-adult-victims.html $>$ at 26 May 2008; Statement of Government
} 
While it remains to be seen what form the new legislation will take, a spokesperson for the Attorney-General, Rob Hulls, stated that ' $[\mathrm{t}] \mathrm{he}$ Sentencing Advisory Council has made a number of safeguards to prevent abuse of the system', and that the 'Government is going to be giving this careful consideration, ${ }^{83}$ More recently the Victorian Corrections Minister, Bob Cameron, has stated that ' $[t]$ he new scheme will draw on the Sentencing Advisory Council's recommendations in its final report to Government ... and by $[\mathrm{sic}]$ what has been learnt from the operation of existing schemes' ${ }^{84}$

\section{JUDICIAL TREATMENT OF EXPERT PSYCHIATRIC EVIDENCE UNDER THE DP(SO)A}

In proceedings under the $D P(S O) A$, judges are required to refer to a number of evidentiary factors, contained in section 13(4), and outlined in Part II.A above. Amongst these factors are the risk assessment reports of two psychiatrists, ${ }^{85}$ and any other psychiatric or psychological reports that are available. ${ }^{86}$ This is the most critical evidence for judges when determining whether a prisoner poses an unacceptable risk of re-offending if released without supervision. However, the system's reliance upon this evidence, and the question of whether this evidence is admissible, has been particularly controversial.

This Part explores the admissibility of expert psychiatric risk assessments by reference to the main rules of expert evidence, which apply to proceedings under the Act. Part III.C.1 asks whether there is an area of expertise regarding predictions of re-offending, Part III.C.2 asks what qualifies a witness in the area of expertise, Part III.C. 3 asks whether the basis for the expert opinion been established, and Part III.C.4 asks whether the evidence addresses the ultimate issue. Part III.D briefly touches on the issue of biased witnesses. These Parts also identify and analyse the way in which judges have applied these rules, and treated this evidence when handing down their judgments.

\footnotetext{
Intentions: 6.3 Serious Sex Offenders (2008) The State Government of Victoria $<$ http://www.yoursay.dpc.vic.gov.au/6communities/6.3offenders.html $>$ at $10 \mathrm{March}$ 2008.

${ }^{83}$ Natasha Robinson, 'Hulls in Clash on Charter of Rights', The Australian, 6 July 2007 ,

$<$ http://acthra.anu.edu.au/media/Hulls\%20in\%20clash\%20on $\% 20$ charter\%20of $\% 20$ ri ghts.pdf $>9$ September 2007.

${ }^{84}$ Premier of Victoria, above $\mathrm{n} 82$.

${ }^{85} D P(S O) A$ s $13(4)(a)$.

${ }^{86} \mathrm{DP}(\mathrm{SO}) A \mathrm{~s} 13(4)(\mathrm{b})$.
} 


\section{A What is Expert Evidence?}

Within the law of evidence there exists a general rule 'that it is for the court and not the witness to draw inferences of fact from primary, observed facts ${ }^{87}$ On the other hand, expert witnesses are permitted to provide the court with their opinions in situations where inexperienced persons are unlikely to prove capable of forming a correct judgment ... without such assistance', ${ }^{88}$ and the witness has expertise in making inferences in a recognised area of expert knowledge. The purpose of such evidence, according to Lord President Cooper in Davie v Edinburgh Magistrates, ${ }^{89}$

is to furnish the judge or jury with the necessary scientific criteria for testing the accuracy of their conclusions, so as to enable the judge or jury to form their own independent judgment by the application of these criteria to the facts proved in evidence. ${ }^{90}$

Despite the ever increasing importance of expert witnesses, particularly in relation to forensic psychiatry and psychology, there is a tendency within the legal profession and the broader community to perceive them as witnesses who will provide favourable evidence to whichever side has commissioned their opinion. Therefore, while psychiatrists and psychologists have an invaluable role to play within the court system, the integrity of this system can only be maintained if their evidence is based on the results of psychological research and if their role is limited to that of consultants rather than advocates. This is as important for the integrity of the psychological professions as it is for the court system, and accordingly, the professions themselves have begun to develop guidelines relevant for their purposes. ${ }^{91}$ While this is noteworthy, the balance of this Part will focus on the admissibility of the evidence that expert psychological witnesses may provide.

\footnotetext{
${ }^{87}$ Sherrard $v$ Jacob [1965] NI 151, 156 (Lord MacDermott LCJ).

${ }^{88}$ Notes to Carter v Boehm (1766) 3 Burr 1905; 97 ER 1162 in 1 Smith LC, approved by Dixon CJ in Clark v Ryan (1960) 103 CLR 486, 491. ${ }^{89}$ (1953) SC 34.

${ }^{90}$ Ibid. 40.

${ }^{91}$ See, eg, James R P Ogloff \& Steven Cronshaw, 'Expert Psychological Testimony: Assisting or Misleading the Trier of Fact? (2001) 42 Canadian Psychology 87.
} 


\section{B Questions about the Admissibility of Expert Evidence under the DP(SO)A}

The successful operation of the $D P(S O) A$ is premised on the reception of expert psychiatric evidence. However, some authors have expressed concerns about the admissibility of evidence the type required by the $D P(S O) A$. In an article published just prior to the Act's introduction, David Ruschena argued that

expert opinion evidence as to dangerousness involves predictions taken outside of the context in which the profession intends them to be made; requires normative comparisons which are neither articulated nor derived from the professions [sic] teachings; and fails to achieve the necessary accuracy. Therefore, such predictions fail to pass the relevant legal steps at virtually every step to admissibility. ${ }^{92}$

Following the High Court's decision in Fardon, and with Ruschena's comments in mind, Professor McSherry stated that '[c]ertainly, there is room for legal challenges to the admissibility of such evidence'. ${ }^{33}$ As the rules of evidence apply to proceedings under the $D P(S O) A,{ }^{94}$ and considering the status of expert psychiatric evidence within post-sentence detention schemes, it is important to address the concerns of these authors.

C The Admissibility of Psychiatric Evidence under the $D P(S O) A$

1 Is There an Area of Expertise regarding Predictions of Re-offending?

(a) The Legal Tests for an Area of Expertise

Since the 1980s, Australian courts have sought to restrict the areas of expertise from which expert evidence can be proffered to those which form 'part of a body of knowledge or experience which is sufficiently organised or recognised to be accepted as a reliable body of knowledge or experience'. ${ }^{95}$ According to Freckelton and Selby, when determining whether the evidence of an expert witness should be admitted or not, Australian courts appear to

\footnotetext{
${ }^{92}$ David Ruschena, 'Determining Dangerousness: Whatever Happened to the Rules of Evidence?' (2003) 10 Psychiatry, Psychology and Law 122, 127-128.

${ }^{93}$ McSherry above n 14, 106.

${ }^{94} D P(S O) A$ s $45(3)$.

${ }^{95} R$ v Bonython (1984) 15 A Crim R 364, 366 (King CJ).
} 
favour the test taken from the American case Frye v United States ${ }^{96}$ which asks whether the theory or technique relied upon by the witness is generally accepted within the field of endeavour to which it belongs. ${ }^{97}$

While the High Court has yet to make an authoritative statement as to the status of the general acceptance test within the Australian context, in the United States, the Frye test has been replaced by that used in Daubert $v$ Merrell Dow Pharmaceuticals Inc. ${ }^{98}$ The Daubert test focuses upon the reliability of the theory or technique, in the sense of whether or not it can produce consistent results. This enables it to assess a broad variety of expert evidence, as opposed to the Frye test, which is most effective when assessing the admissibility of new scientific theories and techniques.

In Australia, the courts have been on the whole unenthusiastic about the Daubert test. Their caution has been justified on the basis that the Daubert test was formulated following the introduction of the Federal Rules of Evidence, which have reduced the comparative value of the American jurisprudence on this issue for Australian purposes. Furthermore, while the Frye test has been superseded in the United States, the principle it supported has not been expressly reversed, which means that the theoretical underpinnings for its use in Australia may well remain intact. ${ }^{99}$ For these reasons, the Daubert test has, for the most part, been distinguished from application in Australia.

\section{(b) The Psychiatric Assessment Methods, their Level of Acceptance and their Accuracy}

The three main methods that are used by psychiatrists and other mental health professionals to determine the likelihood of recidivism are clinical predictions of dangerousness, actuarial assessments of risk, and structured clinical judgments.

Clinical predictions of dangerousness were, for many years, the standard practice for mental health professionals. Put very simply, the concept of dangerousness is used to describe the level of danger that an individual poses

\footnotetext{
96293 F 2d 1013 (1923).

${ }^{97}$ Ian Freckelton and Hugh Selby, Expert Evidence: Law, Practice, Procedure and Advocacy $\left(3^{\text {rd }}\right.$ ed, 2005) 68.

98125 L Ed 2d 469 (1993).

${ }^{99} R$ v Pantoja (1996) 88 A Crim R 554, 558 (Hunt CJ at CL).
} 
to the community. ${ }^{100}$ Clinical predictions involve the unaided exercise of a professional's clinical judgment, and are based upon the observation of and interaction with the subject. Despite the method's orthodoxy, a number of studies published in the 1970s and 1980s questioned the ability of clinicians to make accurate predictions of dangerousness. ${ }^{101}$ More recently, Smallbone and Ransley have observed that ' $[\mathrm{t}]$ he accuracy of clinical prediction, which relies solely on professional judgment, has at best proved to be only slightly better than chance'. ${ }^{102}$ While not the only factor, it was the unreliability of dangerousness which led primarily to the rise in popularity of risk assessments as the method of choice among mental health professionals. ${ }^{103}$

Actuarial risk assessments work through analysis of an offender against a list of risk factors, resulting in a statistical impression of the offender's risk of recidivating. The risk factors and their effect on the likelihood of recidivism are compiled through retrospective studies of known recidivist populations. Research regarding the accuracy of actuarial assessments suggests that they 'undoubtedly improve the consistency of risk assessment', ${ }^{104}$ and are $10 \%$ more accurate than clinical predictions. ${ }^{105}$ One of the more common actuarial instruments is the Static-99, which was found in a Canadian study to predict sexual recidivism accurately in $71 \%$ of cases, and violent recidivism in $69 \%$ of cases. ${ }^{106}$ These percentages represent the "probability that a randomly selected recidivist would have a more deviant score than a randomly selected nonrecidivist', ${ }^{107}$ thereby measuring their likelihood of re-offending.

\footnotetext{
${ }^{100}$ Gelb, above n 3, 21.

${ }^{101}$ See, eg, J J Cocozza and H J Steadman, 'The Failure of Psychiatric Predictions of Dangerousness: Clear and Convincing Evidence' (1976) 29 Rutgers Law Review 1084; T P Thornberry and J E Jacoby, The Criminally Insane: A Community Followup of Mentally Ill Offenders (1979); J Monahan, 'The Prediction of Violent Behaviour: Towards A Second Generation of Theory and Policy' (1984) 141 American Journal of Psychiatry 10.

${ }^{102}$ Stephen Smallbone and Janet Ransley, 'Legal and Psychological Controversies in the Preventive Incapacitation of Sexual Offenders' (2005) 28 University of New South Wales Law Journal 299, 304.

${ }^{103}$ Gelb, above n 3, 21.

${ }^{104}$ M Dolan and M Doyle, 'Violence Risk Prediction: Clinical and Actuarial Measures and the Role of the Psychopathy Checklist' (2000) 177 British Journal of Psychiatry 303, 304.

${ }^{105}$ Leam A Craig, Kevin D Brown, Ian Stringer and Anthony Beech, 'Sexual Recidivism: A Review of Static, Dynamic and Actuarial Predictors' (2005) 11 Journal of Sexual Aggression 65, 73.

${ }^{106}$ R Karl Hanson and David Thornton, Static 99: Improving Actuarial Risk Assessments for Sex Offenders 1999-02 (1999) 16.

${ }^{107}$ Ibid 9.
} 
While actuarial assessments of risk are, on the whole, more reliable than clinical predictions, they have been criticised for their inflexibility. This inflexibility is caused particularly by their focus on historical factors, such as whether the offender was abused as a child, which remain static even though an offender's circumstances will change with time. For example, according to Dolan and Doyle,

[i]t is possible that historical/static variables may be relatively good predictors of violent recidivism in subjects with personality disorder, but clinical and risk management variables may be better predictors in populations with schizophrenia. ${ }^{108}$

Structured clinical judgments are a combination of clinical and actuarial approaches, and 'promote systematic data collection based on scientific knowledge, yet allow flexibility in the assessment process' ${ }^{109}$ One such instrument is the Sexual Violence Risk Assessment Scheme (SVR-20), which was found in a retrospective study, based on a Dutch sample, to be 'significantly more accurate in predicting sexual recidivism than the Static-99 risk category' ${ }^{110}$ In fact, the accuracy of the SVR-20 was reportedly $83 \%,{ }^{111}$ which is remarkably high by comparison with other instruments. The most recently developed instrument is the Risk for Sexual Violence Protocol (RSVP), which closely resembles the SVR-20, except that it incorporates guidelines on risk formulation. ${ }^{112}$ Unfortunately, no studies regarding the accuracy of the RSVP could be located, but one reviewer of the technique wrote that 'it would not seem sensible to use the SVR-20 now that the RSVP is available'. ${ }^{113}$

\section{(c) The Admissibility of the Psychiatric Assessment Methods}

The High Court has deemed it appropriate for the results of the psychiatric assessment methods to be received into evidence, Stephen J stating in Veen $v$

\footnotetext{
${ }^{108}$ M Dolan and M Doyle, above n 104, 307.

109 Ibid 304.

${ }^{110}$ Vivienne de Vogel, Corine de Ruiter, Daan van Beek and Gwen Mead, 'Predictive Validity of the SVR-20 and Static-99 in a Dutch Sample of Treated Sex Offenders' (2004) 28 Law and Human Behaviour 235, 246.

${ }^{111}$ Ibid 245.

${ }^{112}$ Tanya Garrett, 'Book Review - The Risk for Sexual Violence Protocol (RSVP) Structured Professional Guideline for Assessing Risk of Sexual Violence' (2005) 11 Journal of Sexual Aggression 319, 322.

${ }^{113}$ Ibid.
} 
$R^{114}$ that if predictions of recidivism 'are to be employed as aids in sentencing, they should at least be the result of thorough psychiatric investigation and assessment by experts possessing undoubted qualifications for the task ${ }^{115}$ However, Stephen J also acknowledged that

[p]redictions as to future violence, even when based upon extensive clinical investigation by teams of experienced psychiatrists, have ... been condemned as prone to very significant degrees of error when matched against actuality. ${ }^{116}$

Despite this acknowledgment, the High Court has yet to undertake any critical evaluation of these methods against either the general acceptance or reliability tests. This is troubling, because while these methods may be generally accepted among mental health professionals, it is for a purpose different from the one for which they are usually employed within the criminal justice system.

In predicting the likelihood of recidivism, the primary design purpose of the three methods outlined above is to assist mental health professionals in reducing the potential for harm by enabling them to identify offenders susceptible to recidivism and develop targeted treatment strategies. ${ }^{117}$ However, these methods have also come to be generally accepted and relied upon by the Australian criminal justice system as a sentencing aid. The main difference in the medical and forensic uses of these methods is the degree of certainty that each field normally requires. Whereas medical treatment seems acceptable, and even desirable, when the predictions are far from certain, interventions by the criminal justice system would normally require a much higher level of certainty. Therefore, one problem is that methods which were not required to have a high degree of certainty are now routinely deployed in an area where such a degree of certainty is always required.

As was shown in the previous part, the assessment methods are far from $100 \%$ accurate, and while their accuracy seems to be improving, it is highly unlikely that they will ever be infallible. Although it may be that a success rate of $70-85 \%$ does equate to the high degree of probability required by the $D P(S O) A$, it would be harder to sustain an argument that such a success rate

\footnotetext{
${ }^{114}$ (1979) 143 CLR 458.

115 Ibid 464-465.

${ }^{116}$ Ibid 464 (Stephen J).

${ }^{117}$ Ruschena, above n 92, 127.
} 
could justify a decision on the basis of certainty beyond reasonable doubt. ${ }^{118}$ Therefore, as was asked by Anthony Gray, is there no other reason than one of mere utility that the lower degree of certainty is sufficient to extend a prisoner's incarceration, when, to imprison the person in the first place, the court must be satisfied to the higher standard? ${ }^{119}$

\section{(d) The Assessing Psychiatrists' Views Regarding the Accuracy of the Assessment Methods}

In presenting expert evidence to proceedings under the $D P(S O) A$, the psychiatrists have taken great care to ensure that the court is under no illusion as to the accuracy of their assessment methods. For example, in handing down the first detention order against Robert Fardon, White J stated that

[b]oth Dr Moyle and Professor Ogloff were careful to stress that present scientific tools did not permit a determination, with a reasonable degree of accuracy, of an individual's likelihood of being violent or re-offending sexually. What has [sic] been developed and validated are risk assessment schemes principally in studies in Canada and the United Kingdom and used in Australia. Those familiar with both the schemes and the person under investigation and having the necessary skills are able to identify with 'some degree of accuracy' the category of risk into which the person is likely to fall. ${ }^{120}$

Another example of such candour was from Professor Nurcombe, who assessed Darren Francis for the purposes of the detention order application against him. In his testimony to the court, Professor Nurcombe acknowledged that the instruments he had used were imperfect. ${ }^{121}$ Despite this, Byrne J granted the detention order against Francis, so that Francis could have the benefit of a specific treatment plan designed by Professor Nurcombe and the other psychiatrists.

When his detention order was reviewed, Francis was again assessed by Professor Nurcombe. On this occasion, the professor

\footnotetext{
${ }^{118}$ See Anthony Gray, 'Standard of Proof, Unpredictable Behaviour and the High Court of Australia's Verdict on Preventive Detention Laws' (2005) 10 Deakin Law Review 177.

${ }^{119}$ Ibid 194-195.

${ }^{120}$ Attorney-General v Fardon [2003] QSC 379 (Unreported, White J, 6 November 2003) [78].

${ }^{121} R J$ Welford, A-G for the State of Qld v Francis [2004] QSC 233 (Unreported, Byrne J, 13 August 2004) [15].
} 
accepted that it was doubtful that the accuracy of prediction of sexual violence will ever exceed 50\% notwithstanding improved research designs correcting flaws in earlier methodology ... [He also] pointed out that the actuarial findings were Canadian in origin and involved mixed groups of child molesters and rapists. Therefore the validity of the findings for an Australian population and for sexual sadists was unknown. ${ }^{122}$

Furthermore, Professor Nurcombe and the other assessing psychiatrists, Dr Moyle and Dr Hogan, all 'accepted that predicting future violence by an individual was necessarily imprecise', insofar as '[ $\mathrm{t}]$ here was a tendency to overestimate it ${ }^{123}$ on the part of the assessing psychiatrist.

At the hearing for the first annual review of Fardon's detention order, Dr Nielssen was called by Fardon to give evidence, and suggested that the assessment instruments used by the psychiatrists do not result in predictions of recidivism with 'a high enough degree of probability to meet the standard of evidence required by the Act'. ${ }^{124}$ In Dr Nielssen's opinion, the instruments 'were limited and rather inflexible' and 'he concluded that they were unable to predict the risk of re-offending to a high enough degree of probability to warrant preventative detention in the case of an individual'. ${ }^{125}$ Unfortunately for Fardon, Dr Nielssen was unsuccessful in persuading Moynihan J, who renewed the detention order, despite failing to address Dr Nielssen's specific criticisms.

\section{(e) The Methods used by Psychiatrists when Assessing Prisoners for the Purposes of the DP(SO)A}

In Attorney-General v Van Dessel, ${ }^{126}$ White J quoted Professor Nurcombe, who stated that

[ $\mathrm{t}]$ he celebrated debate between those who advocate actuarial prediction and those who advocate clinical decision making has abated. It is generally conceded that it is as important to have knowledge of statistical base rates for particular sub-groups as it is to have thoughtful, well reasoned clinical

${ }^{122}$ Attorney-General v Francis [2005] QSC 381 (Unreported, Mackenzie J, 21 December 2005) [67].

${ }^{123}$ Ibid [119].

${ }^{124}$ Attorney-General for the State of Queensland v Fardon [2005] QSC 137

(Unreported, Moynihan J, 11 May 2005) [83] quoting Dr Nielssen.

125 Ibid [84].

${ }^{126}$ [2006] QSC 016 (Unreported, White J, 10 February 2006). 
opinion about a particular case. Many established actuarial variables (e.g. the PCL-20) are ultimately based on clinical knowledge and expertise. ${ }^{127}$

In accordance with this, the vast majority of risk assessments carried out under the $D P(S O) A$ by psychiatrists have been based on a combination of all three major prediction methods. Importantly, the psychiatrists have generally employed multiple actuarial and structured clinical judgment instruments. On the other hand, the reports prepared by psychologists, other mental health professionals and social workers, and received into evidence under section 13(4)(b), have consistently been based on clinical assessments alone.

Another strategy employed by the psychiatrists has been generally to utilise particular instruments to isolate specific risks. For example, in order to determine the potential for violent recidivism, the experts have used the Historical/Clinical/Risk Management 20-Item; when testing for psychopothy within prisoners, the presence of which may impact the likelihood of recidivism, they have referred to the Psychopathy Checklist Revised; and when testing for potential sexual recidivism, it is the SVR-20 that is used.

There can be no doubt that these two strategies of multi-instrumentation and targeted instrumentation have increased the reliability of the assessments.

\section{(f) Judicial Statements Regarding the Admissibility of the} Psychiatric Assessments in DP(SO)A Proceedings

While the psychiatrists have outlined flaws in the methodology, and shortcomings in the results, of their assessments, in most of the cases heard under the $D P(S O) A$, the admissibility of the evidence has not been questioned. This could well be because of the multi-instrumentation approach, seemingly adopted by most of the assessing psychiatrists.

In her judgment against Fardon, White $\mathrm{J}$ upheld the admissibility of the psychiatric risk assessments as expert evidence by reference to the test from Bonython, stating that ' $[\mathrm{t}] \mathrm{here}$ is a recognised body of research and scholarly writing in the field of psychiatry concerning the risk of recidivism including of sexual offences'. ${ }^{28}$ This much cannot be questioned, and, since this endorsement, judges have often simply stated that they are satisfied that the

127 Ibid [52].

${ }^{128}$ Attorney-General v Fardon [2003] QSC 379 (Unreported, White J, 6 November 2003) [13]. 
evidence before them is 'cogent and acceptable'. ${ }^{129}$ One notable exception to this was Lyons $J$, who granted a detention order against Nigel Robinson and based it in part on the clinical prediction of Dr Kar. Justice Lyons noted that 'Dr Kar was prepared to categorise the respondent as a dangerous sexual psychopath without the use of any of the usual risk prediction instruments in coming to that conclusion', but stated that 'this [method] is accepted by other experts as a legitimate approach' ${ }^{130}$

Despite the general acceptance of the psychiatric methods, there have been a few occasions where judges have hinted at potential weaknesses in the admissibility of the risk assessments. For example, in Attorney-General for the State of Queensland $v G,{ }^{131}$ which concerned an originating application against the prisoner, the court was informed by Mrs Rowland, the examining psychologist, that '[ $\mathrm{t}]$ he risk assessment was carried out by reference to guidelines which have not been verified as applicable in Australia although they are widely used'. ${ }^{132}$ While 'Mrs Rowland explained that they were simply the best that was available', in Fryberg J's opinion this explanation was 'not a very convincing foundation for their use'. ${ }^{133}$ As explained already in this Part, many of the assessment instruments have been developed through studies of Canadian and European sex offender populations. This being the case, verification is important because there may be variations between the social demographics and general characteristics of violent offender populations in different countries or places, which, unless identified, may lead to a method or instrument being implemented on the basis of false assumptions. This in turn would almost certainly lead to an increase in the inaccuracy of predictions made.

\footnotetext{
${ }^{129}$ See, eg, Attorney-General v Hansen [2006] QSC 35 (Unreported, Mackenzie J, 6 March 2006) [9]; Attorney-General (Qld) v Yeo [2006] QSC 063 (Unreported, Philippides J, 3 April 2006)[41]; Attorney-General for the State of Queensland v Twigge [2006] QSC 107 (Unreported, Mullins J, 17 May 2006) [26]; Attorney General for the State of Qld v B [2006] QSC 227 (Unreported, Douglas J, 3 November 2006) [46]; Attorney-General for the State of Queensland v HTR [2007] QSC 019 (Unreported, Lyons J, 9 February 2007) [55]; Attorney-General for the State of Queensland v Reynolds [2007] QSC 52 (Unreported, Mullins J, 13 March 2007) [18].

${ }^{130}$ Attorney-General for the State of Queensland v Robinson [2006] QSC 328

(Unreported, Lyons J, 1 November 2006) [66].

${ }^{131}$ QSC [2004] 442 (Unreported, Fryberg J, 9 December 2004).

${ }^{132}$ Ibid 8.

${ }^{133}$ Ibid.
} 
Despite his reservations, Fryberg J refrained from dismissing Mrs Rowland's assessment, as her report 'was in Court and cross-examining counsel could have referred to it had it been thought to contain anything of importance'. ${ }^{134}$ The failure of respondent counsel to cross-examine the experts on the science underpinning their assessment methods was also evident in $A-G$ for the State of Qld $v$ Ward.$^{135}$ In this case, Muir $\mathrm{J}$ granted a supervision order against Allan Ward, and stated that ' $[\mathrm{t}]$ here was no challenge in cross-examination to the methodology employed by any of the psychiatrists and no doubt was cast on the substance of the professional opinions expressed'. ${ }^{136}$ According to Ruschena, 'legal practitioners have failed to question the assumptions upon which opinions offered to a court are based, preferring instead to seek contrary opinions', ${ }^{137}$ which could explain the broadly uncritical acceptance by both counsel and judges of the psychiatric evidence, in spite of its apparent flaws.

Another case in which the judge questioned the admissibility of the assessment methods was Attorney-General for the State of Queensland v McLean, ${ }^{138}$ where Dutney J expressed his concern that actuarial instruments are biased against indigenous prisoners. This concern was based on evidence from Professor Nurcombe, who had stated that

[i]t should be pointed out that the predictive statistics upon which the various actuarial instruments to be employed in this case rely are of unknown validity for Indigenous people. North American Indians and Indigenous Australians are raised in homes often affected by family instability, heavy parental alcohol intake, and domestic violence. In other words, the actuarial risk indices (such as SORAG, SVR-20 and PCL-R) may be biased against Indigenous people. Whether or not they are biased is not clear. Predictive risk-assessment tests are currently being developed in Canada for Indigenous people but they have not been fully tested. Whether instruments designed in Canada will be suitable for Indigenous Australians is a further question the answer to which will not be available before the next five to ten years. Until then, it must be conceded that one is forced to rely upon predictive instruments derived from generalised Canadian offender samples. ${ }^{139}$

\footnotetext{
${ }^{134}$ Ibid.

135 [2007] QSC 033 (Unreported, Muir J, 21 February 2007).

${ }^{136}$ Ibid [34].

${ }^{137}$ Ruschena, above n 92, 128.

138 [2006] QSC 137 (Unreported, Dutney J, 17 May 2006).

${ }^{139}$ Ibid [26].
} 
For this reason, Dutney J based his conclusions on the psychiatrists' clinical judgments alone, ${ }^{140}$ although he noted the difficulties in attempting such a severance, and accepted that actuarial 'tests do play a part in the overall assessment of risk'. ${ }^{4}$

\section{$2 \quad$ What Qualifies a Witness in the Area of Expertise?}

In order to provide an expert opinion, a witness must possess a degree of specialised skill or experience commensurate with the status of an expert. ${ }^{142}$ The $D P(S O) A$ states only that each risk assessment report prepared under a risk assessment order must be prepared by 'a person registered as a specialist registrant under the Medical Practitioners Registration Act 2001 in the specialty of psychiatry'. ${ }^{143}$ This appears to suggest that as long as they are a registered specialist, any psychiatrist will be considered competent to conduct risk assessments under the Act, regardless of their skill or experience in this specific field.

In Part III.C.1(e) above it was mentioned that psychologists, as well as psychiatrists, have given evidence under the $D P(S O) A$. While psychologists are not permitted to prepare assessments the subject of risk assessment orders, they are permitted to give evidence for the purpose of originating applications and under section 13(4)(b), which requires the court to have regard to, among other things, any relevant psychological assessment relating to the prisoner. ${ }^{144}$

The expertise rule was invoked in one of the first judgments handed down under the $D P(S O) A$. The judgment concerned an application for an interim detention order against Fardon, about whom two psychiatric reports had been prepared, including one by Dr Larder. Justice Atkinson refused to rely on the report prepared by Dr Larder, despite his specialist registration, stating that he 'lacked previous experience in assessing the dangerousness of a prisoner and the potential for future offending of this type', and that 'the opinion

\footnotetext{
${ }^{140}$ Ibid [53].

${ }^{141}$ Ibid [27].

${ }^{142}$ Weal v Bottom (1966) 40 ALJR 436. Although it is yet to apply to either Queensland or Victoria, s 79 of the Evidence Act 1995 (Cth) similarly states that '[i]f a person has specialised knowledge based on the person's training, study or experience, the opinion rule does not apply to evidence of an opinion of that person that is wholly or substantially based on that knowledge'.

${ }^{143} D P(S O) A$ sch.

${ }^{144} D P(S O) A$ s $13(4)(\mathrm{b})$.
} 
expressed was outside his area of expertise'. ${ }^{145}$ Justice Atkinson still granted the order on the basis of the other evidence before him, but the exclusion of Dr Larder's report was an early indication that judges were going to apply the expertise rule in proceedings under the $D P(S O) A$, and not necessarily accept specialist registration as a determinative indication of relevant expertise. However, the expertise of the assessing psychiatrists has not been an issue since this case.

\section{Has the Basis for the Expert Opinion been Established?}

The 'basis rule' provides that the facts upon which experts 'base their opinions must be proved by admissible evidence'. ${ }^{146}$ This rule generally restricts experts from presenting an opinion to the court that has been formulated on the basis of material provided to them in hearsay, unless the material relied upon is

information of the type which scientific experts of the relevant categories ordinarily treat as data on which they may rely in forming opinions and making decisions within the area of their expertise. ${ }^{147}$

In other words, while experts cannot rely on hearsay evidence regarding the treatment history of a person they are testifying about unless other witnesses have given evidence regarding that history, they may provide opinions which have been formulated on the basis of data or models provided in, for example, authoritative publications. This exception would therefore include the assessment methods outlined above, and there is no suggestion from any party in any of publicly available judgments that these models are by their nature hearsay evidence.

In $A-G v$ Watego,${ }^{148}$ the originating application against David Watego was denied by Muir J, as his Honour determined the evidence from Dr Kar and Ms Skye to be inadmissible by reference to the basis rule. ${ }^{149}$ This case is particularly significant, as it appears to be the only case heard under the $D P(S O) A$ where an application has failed as a result of the expert evidence being declared inadmissible.

\footnotetext{
${ }^{145} A-G v$ Fardon [2003] QSC 331 (Unreported, Atkinson J, 2 October 2003) [61].

${ }^{146} R$ v Turner [1975] 1 QB 834, 840.

${ }^{147} P Q v$ Australian Red Cross Society [1992] 1 VR 19, 34 (McGarvie J).

148 [2003] QSC 367 (Unreported, Muir J, 31 October 2003).

${ }^{149}$ Ibid [31].
} 
When filing an originating application, the applicant must submit to the court any affidavits to be relied upon when seeking any preliminary, risk assessment, or interim orders. ${ }^{150}$ Section $7(1)$ of the $D P(S O) A$ specifies that such affidavits 'must be confined to the evidence the person making it could give if giving evidence orally', 151 which is an articulation of the 'basis rule'. While Dr Kar did also interview Watego, his affidavit was based in part on various unidentified reports from other practitioners, and a package of material, the contents of which were also unidentified. ${ }^{152}$ Justice Muir opined that

[t]o allow evidence of the nature of that contained in Dr Kar's report, to use the words of Thomas J in Deputy Commission of Taxation $v$ Ahern, "would virtually permit trial by assertion in circumstances where no real check was available upon facile or erroneous assertion". ${ }^{153}$

Ms Skye's affidavit was based on exhibited reports that Muir J described as relying on 'unproven hearsay evidence'. ${ }^{154}$ His Honour further stated that 'it is impossible to establish whether the relevant opinions would have been formed if Ms Sky [sic] relied only on admissible evidence'. ${ }^{155}$

Justice Muir's reasoning was upheld on appeal, the Queensland Court of Appeal confirming that his Honour was entitled to declare the affidavits of both witnesses inadmissible, ${ }^{156}$ and reduce the weight accorded to Dr Kar's oral evidence due to doubts about the doctor's ability to distinguish between the hearsay evidence and his own assessment of Watego. ${ }^{157}$ The Watego decisions therefore suggest that it is unsatisfactory for experts providing psychiatric evidence under the $D P(S O) A$ to rely solely on reports from other practitioners, or to make broad references to unspecified documentation even where an interview with the prisoner has been conducted. Unsurprisingly, establishing the basis of the expert opinion has not been in issue again since the Watego decisions.

\footnotetext{
${ }^{150} D P(S O) A$ s $5(2)(\mathrm{b})$.

${ }^{151} D P(S O) A$ s $7(1)$.

${ }^{152} A$-G v Watego [2003] QSC 367 (Unreported, Muir J, 31 October 2003) [23-24].

${ }^{153}$ Ibid [27] quoting [1988] 2 Qd R 158, 163.

${ }^{154}$ Ibid [30].

${ }^{155}$ Ibid.

${ }^{156}$ A-G Qld v Watego [2003] QCA 512 (Unreported, McPherson, Davies JJA and Mullins J, 17 November 2003) [10].

${ }^{157}$ Ibid [12].
} 


\section{$4 \quad$ Does the Evidence Address the Ultimate Issue?}

It is a long held principle of the law of evidence that '[i]t is not competent in any action for witnesses to express their opinion upon any of the issues, whether of fact or law, which the court or a jury has to determine'. ${ }^{158}$ In $R v$ Palmer, ${ }^{159}$ Glass JA defined this rule as meaning that '[n]o evidence can be received upon any question, the answer to which involves the application of a legal standard' ${ }^{160}$ While there are a number of rationales buttressing this rule, one of the most convincing is that expert comment upon the central or ultimate issue would usurp the essential function of the tribunal of fact. ${ }^{161}$

The ultimate question that judges deliberating over $D P(S O) A$ applications must answer is whether the prisoner is a serious danger to the community. ${ }^{162}$ While the psychiatric reports prepared under risk assessment orders must indicate the level of risk that a prisoner may pose should he be released, or released without a supervision order, ${ }^{163}$ the psychiatrists are not required to comment on whether they believe this level of risk to be acceptable or not. The Act does not therefore appear to offend the 'ultimate issue' rule. In Attorney-General for the State Of Queensland v Sutherland, ${ }^{164}$ McMurdo J agreed with this interpretation, explaining that

the assessment of what level of risk is unacceptable, or alternatively put, what order is necessary to ensure adequate protection of the community, is not a matter for psychiatric opinion. It is a matter for judicial determination, requiring a value judgement as to what risk should be accepted against the serious alternative of the deprivation of a person's liberty. ${ }^{165}$

The Court of Appeal concurred, deciding in $A-G($ Qld $) v$ Robinson $^{166}$ that regardless of the recommendations of the psychiatrists, the discretion whether to make an order or not, and what exact order to make, lies with the judges. ${ }^{167}$

\footnotetext{
${ }^{158}$ Joseph Crosfield \& Sons Ltd v Techno-Chemical Laboratories Ltd (1913) 29 TLR 378, 379 (Neville J). It is important to note that s 80 of the Evidence Act 1995 (Cth) has abolished this rule, however the Act is yet to apply to either Queensland or Victoria.

159 [1981] 1 NSWLR 209.

160 Ibid 214.

${ }^{161}$ See, eg, $R v$ Ashcroft [1965] Qd R 81, 85 (Gibbs J).

${ }^{162} \mathrm{DP}(\mathrm{SO}) \mathrm{A}$ s 13.

${ }^{163} \mathrm{DP}(\mathrm{SO}) \mathrm{A}$ s $11(2)(\mathrm{a})$.

164 [2006] QSC 268 (Unreported, McMurdo J, 27 September 2006).

165 Ibid [30].

166 [2007] QCA 111 (Unreported, Keane, Holmes JJA and Douglas J, 5 April 2007).
} 
While the psychiatric evidence may not address the 'ultimate issue', its importance to judges sitting in $D P(S O) A$ proceedings cannot be underestimated. This importance has been recognised by a number of the Supreme Court's judges. For example, Mullins J described the evidence received in one case as 'particularly helpful'. ${ }^{168}$ In Attorney-General for the State of Queensland $v$ Waghorn, McMurdo J suggested that

the most important evidence ... was that of three psychiatrists each of whom also gave oral evidence ... and ultimately the outcome turns upon the effect to be given to the psychiatric evidence. ${ }^{169}$

In Attorney-General for the State of Queensland v Toms, ${ }^{170}$ Chesterman J characterised Dr Lawrence and Dr Grant as 'both eminent forensic psychiatrists in whose opinions the Court is accustomed to place great confidence'. ${ }^{171}$ On the other hand, Moynihan J agreed that, on the whole, the psychiatric reports were 'an important component' of his evaluation, but maintained also that his 'decision was based on the whole of the evidence'. ${ }^{172}$

The obvious capacity of the experts and their evidence to influence judicial decision-making indicates the necessity for judges to remain vigilant in ensuring that these experts do not stray onto the ultimate issue. In New Zealand, where preventive detention has been in operation for some time, the potential for the witness to 'prejudice the offender's case or mislead the court about a psychiatrist's ability to make valid predictions' caused psychiatrists to decide 'against addressing the issue of substantial risk directly'. ${ }^{173}$ Instead, most psychiatrists express their 'opinion in terms of treatment needs and positive and negative prognostic factors'. ${ }^{174}$

\footnotetext{
${ }^{167}$ Ibid [27].

${ }^{168}$ Attorney-General for the State of Queensland v Twigge [2006] QSC 107

(Unreported, Mullins J, 17 May 2006) [24].

${ }^{169}$ [2006] QSC 171 (Unreported, McMurdo J, 14 July 2006) [3].

${ }^{170}$ [2006] QSC 298 (Unreported, Chesterman J, 20 October 2006).

${ }^{171}$ Ibid [11].

${ }^{172}$ Attorney-General for the State of Queensland v Fardon [2005] QSC 137, (Unreported, Moynihan J, 11 May 2005) [85].

${ }^{173}$ Alexander I F Simpson, 'Psychiatrists' Role in Preventive Detention: New

Zealand's Legislation for Indefinite Detention' (1988) 5 Psychiatry, Psychology and

Law 87, 92.

174 Ibid.
} 


\section{The Problem of Biased Experts}

The analysis of available judgments made under the $D P(S O) A$ has revealed that there is only a very small number of psychiatrists who give evidence to the court. In fact, the vast majority of the psychiatric evidence was prepared and delivered by only five different psychiatrists. ${ }^{175}$ While evidence was not supplied by this group exclusively, of the 85 times that psychiatrists provided evidence within the available judgments, these five psychiatrists were the source of this evidence a total of 67 times. Most of this evidence was in the form of reports prepared under risk assessment orders, although there were also occasions where these psychiatrists had prepared reports to be submitted with the originating application, or where reports prepared by these psychiatrists in the normal course of penal administration and prisoner treatment were submitted as evidence under section 13(4)(b). For example, the psychiatric evidence used by White $\mathrm{J}$ to help her determine that a detention order was appropriate for Fardon included a report from Professor James, who 'had had previous dealings with the respondent at the request of Queensland Corrective Services'. ${ }^{176}$

That there are a limited number of psychiatrists providing evidence could very well be because there are not many practitioners in Queensland with the necessary expertise. However, with so few experts conducting assessments, the effect of any actual or unconscious bias would be magnified throughout the relevant population of prisoners. While expert evidence presented by a biased witness may not necessarily be excluded under Australian law, the weight given to that evidence may be affected should the witness's bias be demonstrated under cross-examination. ${ }^{177}$

\section{$1 \quad$ Actual Bias}

Actual bias could be a factor in the risk assessments of a psychiatrist if they possess pre-determined attitudes regarding a particular prisoner, or group of prisoners within the sex offender population.

\footnotetext{
${ }^{175}$ In no particular order, the five psychiatrists are Professor Nurcombe, Dr Lawrence, Dr Moyle, Dr Grant, and Professor James.

${ }^{176}$ Attorney-General v Fardon [2003] QSC 379 (Unreported, White J, 6 November 2003) [14].

${ }^{177} R$ on the Application of Factortame Ltd $v$ Secretary of State for Transport (No 8) [2002] 3 WLR 1104. This case is a United Kingdom authority for this proposition.
} 
As far as could be determined from the publicly available judgments, there has to this point been only one accusation of actual bias levelled at a psychiatrist who has presented evidence in a $D P(S O) A$ related proceeding. This occurred during Fardon's first annual detention order review, where it was argued by Fardon's counsel that Dr Moyle, who had prepared a report for the review under a risk assessment order, had pre-determined views about the respondent, and had based his evidence on falsehoods. ${ }^{178}$ The accusation arose because Dr Moyle had also assessed Fardon before the first detention order was granted against him. However, as Fardon's counsel could neither identify nor demonstrate the supposed falsehoods, Moynihan J rejected the argument. ${ }^{179}$ According to Moynihan J, the 'fact that a witness has previously expressed a view adverse to the respondent does not justify a finding of bias'. ${ }^{180}$

\section{Unconscious Bias}

As stated by Walsh J in Miller Steamship Co Pty Ltd v Overseas Tankship (UK) $L t d,{ }^{181}$ while an expert's evidence may have been prepared honestly and in good faith, it could also be 'affected in greater or lesser degree by the kind of unconscious bias which is a well known characteristic of expert evidence'. ${ }^{182}$

Unconscious bias can occur when 'experts hold strong beliefs in theories or hypotheses about particular issues or subject matters and frequently do so from the purest and most altruistic of motives' ${ }^{183}$ It can also occur as a result of an expert's familiarity with the system, which can cause them to 'become accustomed to focusing on a search for indicia of guilt', ${ }^{184}$ or risk in the case of the $D P(S O) A$. Furthermore, an expert

\footnotetext{
${ }^{178}$ Attorney-General for the State of Queensland v Fardon [2005] QSC 137, (Unreported, Moynihan J, 11 May 2005) [28-30].

${ }^{179}$ Ibid [33].

${ }^{180}$ Ibid [31].

${ }^{181}$ [1963] SR (NSW) 948.

182 Ibid 963 (Walsh J).

${ }^{183}$ Robert Stitt QC, 'Cross-examination of Expert Witnesses: A Practical Approach via a Personal Excursion' (2005) 26 Australian Bar Review 219, 220.

${ }^{184}$ Justice J R T Wood, 'Forensic Sciences from the Judicial Perspective' (2003) 23 Australian Bar Review 137, 156.
} 
may learn to adjust his or her testimony to accommodate potential problems, and may also learn how to present an aura of confidence and persuasiveness, in a way which will be dismissive of any challenge. ${ }^{185}$

There is no suggestion in the judgments analysed that there are problems of this nature within the group of assessing psychiatrists.

\section{Judicial BaLANCING of Community PROTECTION AND LIBERTY UNDER THE DP(SO)A}

\section{A The Pressure on Judges to Deny Prisoners their Liberty under the DP(SO)A}

The objects of the $D P(S O) A$ are 'to ensure adequate protection of the community' and 'to provide continuing control, care or treatment of a particular class of prisoner to facilitate their rehabilitation'. ${ }^{186}$ From the way these objects are framed, it appears as if the Act tries to balance the competing interests of the community on the one hand, and of the prisoner on the other. However, even though the Act authorises continued detention beyond the expiration of the prisoner's sentence, its only explicit concession in favour of the prisoner's liberty appears to be the annual reviews that must be conducted of all detention orders. ${ }^{187}$ Furthermore, the Act stipulates that the judge's 'paramount consideration' when deciding whether or not to make an order against a prisoner 'is to be the need to ensure adequate protection of the community'. ${ }^{188}$ It is this last direction that appears to tip the balance firmly in favour of community protection. In fact, when granting an interim detention order against Fardon, Mackenzie J declared that ' $\mathrm{t}]$ he legislation's apparent intent is to subjugate the interests of the prisoner to the interest of the public'. ${ }^{189}$

According to Anthony Gray, the practical effect of the $D P(S O) A$ 's favouring of community protection is that 'a court with doubts as to whether it should grant the application is encouraged to err on the side of caution', ${ }^{190}$ and grant a detention order. As it is impossible ever to predict with absolute certainty

\footnotetext{
185 Ibid 151.

${ }^{186} \mathrm{DP}(\mathrm{SO}) \mathrm{A}$ s 3.

${ }^{187} D P(S O) A$ s 27.

${ }^{188} \mathrm{DP}(\mathrm{SO}) \mathrm{A}$ s $13(6)$.

${ }^{189}$ Welford, Attorney-General v Francis [2004] QSC 128 (Unreported, Mackenzie J, 5 May 2005, [5].

${ }^{190}$ Anthony Gray, 'Preventive Detention Laws: High Court Validates Queensland's

Dangerous Prisoner's Act 2003' (2005) 30 Alternative Law Journal 75, 76.
} 
whether a prisoner will re-offend or not, it is inevitable that judges will be, at times, in a state of doubt when deciding whether to grant an order or not. Moreover, there is no way for a judge to guarantee absolutely that the community will be protected from a prisoner, other than by granting a detention order. Therefore, Gray's presumption is by no means an unreasonable one.

An added pressure upon judges to err on the side of community protection is the prospect of public criticism should they release a prisoner, who then reoffends. Following the eventual release of Fardon, and his subsequent breaches of the supervision order imposed against him, ${ }^{191}$ as well as a parole order, Queensland Police Minister Judy Spence said that 'she believed the court held a different view about allowing sex offenders into the community than the general public'. ${ }^{192}$ In response, Chief Justice Paul de Jersey of the Queensland Supreme Court was forced to make a statement defending the integrity of the Court. The Chief Justice expressed his belief that judges are not out of touch with respect to the community's concerns regarding sex offenders, stating that

judges accept, that these are areas of enormous concern to the community community protection is the prime consideration in these cases ... Judges are acutely alive, judges are members of the community of course, it's a fallacy to think that in some way they're separated from the communities, judges do their best to address these concerns ... [W]e don't claim to be infallible but we've crafted a system to ensure if the judge does get it wrong then there's an avenue for correction on appeal. ${ }^{193}$

The Chief Justice also said that the Fardon experience would influence judges to 'contemplate a little longer' over the decision whether to release prisoners

\footnotetext{
${ }^{191}$ It is important to remember that supervision orders can contain whatever terms the judge deems necessary to prevent the prisoner from committing a further serious sexual offence (s 16). These terms need not be limited to criminal offences. Fardon's supervision order contained 32 terms, and he was twice in breach of one or more, but not all, of these terms. He first breached the order in December 2006 when he was found in the presence of Trevor Toms, who himself was in breach of a curfew order. Fardon breached his order a second time, in July 2007, when he failed to attend a meeting with his parole officer.

192 'All Sex Offenders to be monitored', The Daily Telegraph, 24 July 2007

$<$ http://www.news.com.au/dailytelegraph/story/0,22049,22125505-

$5001028,00$. html $>23$ July 2008.

193 'Judge Defends System after Fardon Arrest', The Daily Telegraph, July 252007 $<$ http://www.news.com.au/dailytelegraph/story/0,22049,22125286$5001028,00$. html $>2$ October 2007.
} 
into the community. ${ }^{194}$ This comment acutely demonstrates the politicisation of the judiciary by the $D P(S O) A$, particularly when it is remembered that Fardon is not known to have committed any criminal offences while under the supervision order.

Despite the pressure on judges to impose detention orders upon prisoners, and 'although incapacitative policies may be popular with the public and governments, [research indicates that] a juridical tradition has developed which is generally resistant to such policies'. ${ }^{195}$ A study by Richardson and Freiberg focused on changes to the serious offender provisions within the Sentencing Act 1991 (Vic), designating community protection as the primary purpose for imposing a prison sentence upon a serious offender. ${ }^{196}$ It demonstrated that these changes had not resulted in significant numbers of sentences being imposed that were disproportionate in length to the gravity of the contemporary offence for which the offender was appearing. ${ }^{197}$ Whatever the reason for its results, this study provides cause to believe that if Queensland judges are at all like those from Victoria, then the pessimistic outlook expressed above on the way that judges may react to the pressures upon them when making orders under the $D P(S O) A$, could be ill founded.

\section{B Judicial Solutions to the Problem of Balancing Community Protection with Prisoners' Liberty}

According to a representative of the Queensland Department of Justice interviewed on 12 July 2007, the Department's records indicated that that at that time, 38 post-sentence orders had been granted against sex offenders in the fours years since the enactment of the $D P(S O) A$. These included eight detention orders and 30 supervision orders. Three of the detention orders were no longer being enforced due to either the offender's death ${ }^{198}$ or the replacement of the detention order with a supervision order, ${ }^{199}$ and three

\footnotetext{
194 Ibid.

${ }^{195}$ Elizabeth Richardson and Arie Freiberg, 'Protecting dangerous offenders from the community: The application of protective sentencing laws in Victoria' (2004) 4 Criminal Justice 81, 85.

${ }^{196}$ Ibid 82-83, citing Sentencing Act 1991 (Vic) s 5A(a), now s 6D(a), (b).

197 Ibid 91.

198 This prisoner who died was Jesse Pearce.

${ }^{199}$ The prisoners who had their detention orders replaced with supervision orders were Fardon and Francis.
} 
offenders had breached their supervision orders. ${ }^{200}$ The officer also stated that seven applications were currently before the court.

A day later, on 13 July 2007, the Queensland Police Minister, Judy Spence, was quoted in The Australian as saying that at that time, 36 orders were in force, including nine detention orders and 27 supervision orders. ${ }^{201}$

These figures accord roughly with those quoted by Chesterman J in AttorneyGeneral for the State of Queensland v Murry, ${ }^{202}$ which was heard in late May 2007. In that case, Counsel for the Attorney-General informed his Honour that 23 supervision orders had been granted, and that four of these orders, not three as stated by the Department of Justice officer, had apparently been breached. However, Chesterman J was unequivocal in his statement that no offender was known to have re-offended sexually upon release under a supervision order. ${ }^{203}$

While the Department of Justice officer spoken to could not say how many applications had been made in total under the $D P(S O) A$, the officer was aware that all prisoners the subject of applications had been found to pose a serious danger to the community. The few applications that had been rejected were done so on grounds other than the danger posed by the prisoner to the community. ${ }^{204}$

The comparatively high number of supervision orders granted by the judges indicates that, despite the legal and political pressures upon them to impose detention orders, the judges have been somewhat uncomfortable with the prospect of denying prisoners their liberty post-sentence. In Attorney-General

\footnotetext{
${ }^{200}$ The three offenders who breached their supervision orders were Mark Foy, Toms, and Francis. Fardon was arrested for breaching his supervision order on July 24 2007.

201 'Queensland May Change Sex Offender Laws', The Australian, 13 July 2007 $<$ http://www.theaustralian.news.com.au/story/0,20867,22067155-2702,00.html $>21$ October 2007.

202 [2007] QSC 121 (Unreported, Chesterman J, 28 May 2007).

${ }^{203}$ Ibid [5].

${ }^{204}$ This information was provided by Len Brown of the Queensland Department of Justice during a telephone interview on 12 July 2007. The denial of procedural fairness in DP(SO)A cases, and the rejection of applications on this ground, is discussed in Patrick Keyzer and Suzanne O'Toole, 'Time, Delay and Nonfeasance' (2006) 31 Alternative Law Journal 194.
} 
for the State of Queensland $v$ Toms, ${ }^{205}$ Chesterman J stated that '[i]t is no light thing to confine a man to prison for the whole of his life because he might re-offend' ${ }^{206}$ From a legal perspective, this sentiment has been given effect by reference to the "jealousy with which the common law guards personal freedom' ${ }^{207}$ According to Byrne J,

[a]lthough the protection of the community is the 'paramount' consideration, it is not the only consideration. The other, the significance of which scarcely needs elaboration in this Court, relates to liberty of the citizen. ${ }^{208}$

Furthermore, as '[a]dequate protection, not absolute protection is what is referred to' by the Act ${ }^{209}$ the Court of Appeal has stated definitively that there is no requirement that arrangements to prevent risk to the community "must be "watertight"; otherwise [supervision] orders under s 13(5)(b) would never be made' ${ }^{210}$ The effect of these developments appears to have been the alleviation of some of the perceived pressure upon judges from the Act to impose detention orders in borderline cases.

In regard to the political pressure that judges face from the community, McMurdo J acknowledged in Attorney-General for the State Of Queensland $v$ Sutherland ${ }^{211}$ that ' $[\mathrm{m}]$ any in the community would say that adequate protection of the community requires the elimination of any risk of reoffending, ${ }^{212}$ In Murry, Chesterman $\mathrm{J}$ also remarked that '[o]ne hears, sometimes, and from some quarters, a suggestion that prisoners jailed for committing sexual offences, especially against children, should never be released ${ }^{213}$ In response to these concerns, Chesterman J stated,

\footnotetext{
${ }^{205}$ Attorney-General for the State of Queensland v Toms [2006] QSC 298 (Unreported, Chesterman J, 20 October 2006).

${ }^{206}$ Ibid [7].

${ }^{207} A-G$ v Fardon [2003] QSC 331 (Unreported, Atkinson J, 2 October 2003) [32].

${ }^{208} A G v$ Downs [2005] QSC 016 (Unreported, Byrne J, 10 February 2005) 10.

${ }^{209}$ Attorney-General v Francis [2005] QSC 381 (Unreported, Mackenzie J, 21 December 2005) [108].

${ }^{210} A-G(Q L D)$ v Francis [2006] QCA 324 (Unreported, Keane and Holmes JJA, and Dutney J, 30 August 2006) [39].

${ }^{211}$ Attorney-General for the State Of Queensland $v$ Sutherland [2006] QSC 268

(Unreported, McMurdo J, 27 September 2006).

212 Ibid [50].

${ }^{213}$ Attorney-General for the State of Queensland v Murry [2007] QSC 121

(Unreported, Chesterman J, 28 May 2007) [6].
} 
The figures I was given do not support such a position. Only one in six (almost) of those released has not complied with the conditions imposed. Keeping six men in jail indefinitely after they have served their sentence, thereby destroying their lives, scarcely seems justified if only one of them might re-offend if released. The figures suggest that supervision orders are effective to prevent recidivism. ${ }^{214}$

Not only was this conclusion supported by the information provided to Chesterman $\mathrm{J}$ in this case, that no prisoner released under a supervision order had been known to re-offend at that time, ${ }^{215}$ but according to Judy Spence, this information was still accurate as of 24 July $2007 .^{216}$

It is clear that, in most cases, judges have faith in the efficacy of supervision orders to achieve the objects of the Act, and prevent sexual recidivism. This was accepted by the applicant in Van Dessel, who conceded that should the prisoner be found to pose an unacceptable risk to the community, the making of a supervision order was the most likely outcome of the case. ${ }^{217}$ What is interesting, is that in a number of the more recent cases heard under the $D P(S O) A$, not only has respondent counsel been willing to concede that the prisoner would pose an unacceptable risk to the community if released without supervision, ${ }^{218}$ but the applicant has also decided against seeking a detention order. ${ }^{219}$ This indicates the development of a more co-operative and

${ }^{214}$ Ibid.
${ }^{215}$ Ibid [5].
${ }^{216}$ 'All Sex Offenders to be monitored', The Australian, 24 July 2007
$<$ http://www.news.com.au/dailytelegraph/story/0,22049,22125505-
$5001028,00$. html > 23 July 2008.
${ }^{217}$ Attorney-General v Van Dessel [2006] QSC 016 (Unreported, White J, 10

February 2006) [5].

${ }^{218}$ See, eg, ibid; $A G v$ Pearce [2005] QSC 314 (Unreported, Atkinson J, 16 August 2005); Attorney-General v Hansen [2006] QSC 35 (Unreported, Mackenzie J, 6 March 2006); Attorney-General for the State of Queensland v Waghorn [2006] QSC 171 (Unreported, McMurdo J, 14 July 2006); Attorney-General for the State of Queensland v B [2006] QSC 227 (Unreported, Lyons J, 28 August 2006); AttorneyGeneral for the State Of Queensland v Sutherland [2006] QSC 268 (Unreported, McMurdo J, 27 September 2006); Attorney-General for the State of Queensland $v$ Murry [2007] QSC 121 (Unreported, Chesterman J, 28 May 2007).; AttorneyGeneral for the State of Queensland v Reynolds [2007] QSC 52 (Unreported, Mullins J, 13 March 2007).

${ }^{219}$ See, eg, Attorney-General for the State of Queensland v Friend [2006] QSC 131 (Unreported, Moynihan J, 2 June 2006); Attorney-General for the State Of Queensland v Sutherland [2006] QSC 268 (Unreported, McMurdo J, 27 September 2006 ) in which the applicant applied for a detention order, but did not advance any 
therapeutic approach to the $D P(S O) A$ trial process, perhaps based on the recognition that in many cases, far from being opposing, the interests of the community and the prisoner are inextricably linked.

Also of significance in the development of this approach has been the inflexible nature of Queensland's prisoner management policies. Due to the length of time that many prisoners have spent in prison, the assessing psychiatrists have sometimes been of the view that prison services have exhausted their capacity to assist in a prisoner's rehabilitation, and that a graduated release plan would be the most appropriate course of action. The benefit of graduated release is that the prisoner 'can gradually become used to having more freedom and more mobility and gradually interact with society and learn how to cope with the everyday requirements of living as a free person' ${ }^{220}$ However, as prisoners subject to detention orders are generally ineligible for graduated release, the psychiatrists have often concluded that ongoing detention could in fact retard further progress. In these situations, judges have preferred the imposition of a supervision order. According to Lyons J, who rescinded Fardon's detention order,

[g]reater protection may be afforded by way of a graduated release but if adequate protection can still be ensured by way of a supervision order then that is all that is required to meet the requirements of the section. ${ }^{221}$

While the therapeutic approach is of undoubted benefit to the prisoner, it should by no means be considered a 'soft' option. In granting a supervision order against Murry, Chesterman J estimated that

[t]here is some risk that he will re-offend but the slightness of harm that would follow such re-offending may not pass the test. Nevertheless the imposition of a supervision order will remove, or substantially reduce, the risk and it is probably in the respondent's own interest that such an order be made. As he himself has noted 'every time he offends he is caught'. Given

arguments in favour of this choice; Attorney-General for the State of Qld v B [2006] QSC 330 (Unreported, Douglas J, 3 November 2006); Attorney-General for the State of Queensland v Murry [2007] QSC 121 (Unreported, Chesterman J, 28 May 2007); Attorney-General for the State of Queensland v Reynolds [2007] QSC 52 (Unreported, Mullins J, 13 March 2007).

${ }^{220}$ Attorney-General for the State of Queensland v Fardon [2006] QSC 275

(Unreported, Lyons J, 27 September 2006) [106] quoting Dr Grant.

${ }^{221}$ Ibid [112]. 
his criminal history any offence is likely to result in a further term of imprisonment. It is best for all concerned if that is avoided. ${ }^{222}$

This passage demonstrates an example of the therapeutic approach resulting in the imposition of a supervision order where the prisoner may otherwise have been released unsupervised. Furthermore, it should be remembered that the terms of supervision orders are onerous by design. ${ }^{223}$ Should an offender breach any of these terms, the court may amend the supervision order, or rescind it and make a detention order in its place, thereby ensuring that the community is adequately protected. ${ }^{224}$

In the wake of Fardon's highly publicised supervision order breach, and the suspension of his supervision order by White J on 1 August $2007,{ }^{225}$ the Queensland Parliament passed the Dangerous Prisoners (Sexual Offenders) Amendment Act 2007 (Qld) (DP(SO)AA). This Act makes it an offence to breach a provision of a supervision order without reasonable excuse, with a maximum penalty of two years imprisonment. ${ }^{226}$ The $D P(S O) A A$ also empowers corrective services officers to make curfew and/or monitoring directions to prisoners released under supervision orders. ${ }^{227}$ Under a curfew direction, a prisoner must 'remain at a stated place for stated periods', 228 whereas under a monitoring direction, a prisoner must wear a stated device and/or 'permit the installation of any device or equipment at the place where the released prisoner resides'. ${ }^{229}$ Although Judy Spence has said that 'supervision requirements, as they stood, were working, ${ }^{230}$ these amendments suggest that the Queensland judiciary's preference for supervision orders over detention orders in $D P(S O) A$ cases, and its unwillingness to revoke supervision orders in the event of breach, have not pleased the Government.

\footnotetext{
${ }^{222}$ Attorney-General for the State of Queensland v Murry [2007] QSC 121 (Unreported, Chesterman J, 28 May 2007) [20].

${ }^{223} D P(S O) A$ s 16.

${ }^{224} \mathrm{DP}(\mathrm{SO}) \mathrm{A} \mathrm{s} 22$.

225 'Fardon Stays Behind Bars' The Australian, 1 August 2007

$<$ http://www.theaustralian.news.com.au/story/0,25197,22171736-5006786,00.html>

21 October 2007.

${ }^{226} D P(S O) A A$ s 9 inserting a new s 43B.

${ }^{227} D P(S O) A A$ s $3 \mathrm{~A}$ inserting a new s $16 \mathrm{~A}$.

${ }^{228} D P(S O) A A$ s $3 \mathrm{~A}$ (s $\left.16 \mathrm{~A}(2)(\mathrm{a})\right)$.

${ }^{229} D P(S O) A A$ s $3 \mathrm{~A}$ (s $\left.16 \mathrm{~A}(2)(\mathrm{b})\right)$.

230 'All Sex Offenders to be monitored', The Australian, 24 July 2007

$<$ http://www.news.com.au/dailytelegraph/story/0,22049,22125505-

$5001028,00$. html $>23$ July 2008.
} 


\section{CONCLUSION}

This article has demonstrated that the way in which the Queensland judiciary has interpreted and applied the $D P(S O) A$ has been very successful in achieving the Act's stated objects, and particularly the 'adequate protection of the community'. ${ }^{231}$ As outlined in Part IV.B above, only a small percentage of supervision orders have been breached, and no released prisoner is known to have committed a further serious sexual offence. As the Victorian Government has noted its intention to introduce post-sentence detention orders in spite of the VSAC's recommendation against such reform, it is useful to conclude this article with a brief outline of some lessons from Queensland's experience with its post-sentence protection order regime, and how these could be applied in the Victorian context.

One of the reasons that the VSAC recommended against the introduction of post-sentence detention orders was its concern regarding the ability of mental health professionals to predict risk accurately. This article has confirmed those concerns as being reasonably based, but has also suggested that the implementation of multi-instrumentation and targeted instrumentation strategies by the psychiatrists, and the sensible application of the laws of expert evidence by the judiciary, have minimised the likelihood that inaccurate assessments have caused any significantly unjust outcomes in Queensland. For this reason, the VSAC's recommendation that a panel be specially convened and charged with the responsibility for accrediting practitioners to undertake risk assessments and instituting model assessment guidelines should be seriously considered by the Victorian Government. ${ }^{232}$

As mentioned in Part IV.B of this article, the psychiatrists assessing prisoners under the $D P(S O) A$ have occasionally suggested that the most appropriate course of action would be a graduated release plan, an option which judges are currently not empowered to select. This appears to be a serious flaw in the Queensland system, and one with the potential to jeopardise community safety, irrespective of the success of supervision orders. The VSAC has proposed that any Victorian detention orders allow

the offender to be detained or managed in the community ... [and] expressly allow for the possibility of the offender being made subject to other less restrictive forms of control during the period of the order. ${ }^{233}$

${ }^{231} D P(S O) A$ s $3(\mathrm{a})$.

${ }^{232}$ Sentencing Advisory Council, above n 19, 114.

${ }^{233}$ Ibid 83. 
Considering the situation in Queensland, this seems to be an appropriately targeted proposal.

In its Final Report, the VSAC expressed a preference for the revision of Victoria's existing extended supervision scheme, rather than the introduction of detention orders for serious sex offenders. ${ }^{234}$ This accords with what has been shown to be the apparent tendency of Queensland judges towards the making of supervision orders, and there is nothing to suggest that Victorian judges would approach the exercise of their discretion any differently. The Queensland approach appears to have been remarkably successful, insofar as no prisoner has been known to re-offend upon release. This demonstrates that it may not always be necessary to apply draconian measures in order to achieve satisfactory law and order outcomes. However, criticism has remained regarding the strength of the supervision conditions imposed in a number of cases.

Should the Victorian Government press ahead with plans to introduce postsentence detention, it must consider the Queensland experience and appreciate that detention orders are likely to be overshadowed in their use by supervision orders. It is therefore imperative that the Government ensure that any bill introduced into Parliament contains the supervision conditions necessary; not only to ensure that the community is adequately protected, but also to ease the community's sense of fear. In any event, the judicial approach to the $D P(S O) A$ outlined in this article should not be characterised as an exercise in resistance to, or obstruction of, legislative intent. To the contrary, the judges of the Queensland Supreme Court and Court of Appeal have used the $D P(S O) A$ to provide the Australian people with a glimpse of a possible solution to one of the most emotive and pressing issues of the current day.

${ }^{234}$ Ibid 64. 


\section{ApPendix: Publicly Available Judgements Analysed for THIS ARTICLE}

\begin{tabular}{|c|c|c|c|c|c|c|}
\hline No & Name & Date & Proceeding & Judge/s & Psychiatrist/s & Outcome \\
\hline 1. & $\begin{array}{c}A-G v \\
\text { Fardon } \\
\text { [2003] QSC } \\
200\end{array}$ & $\begin{array}{c}9 \\
\text { July } \\
2003\end{array}$ & $\begin{array}{l}\text { Challenge to } \\
\text { constitutionality } \\
\text { of s } 8\end{array}$ & Muir J & N/A & $\begin{array}{l}\text { Challenge } \\
\text { denied }\end{array}$ \\
\hline 2. & $\begin{array}{c}A-G(\text { Qld }) v \\
\text { Fardon } \\
\text { [2003] QCA } \\
416\end{array}$ & $\begin{array}{c}23 \\
\text { Sep } \\
2003\end{array}$ & $\begin{array}{l}\text { Appeal against } \\
\text { denial of } \\
\text { challenge to } \\
\text { constitutionality } \\
\text { of s } 8\end{array}$ & $\begin{array}{c}\text { de Jersey CJ, } \\
\text { McMurdo P } \\
\text { and Williams } \\
\text { JA }\end{array}$ & N/A & $\begin{array}{c}\text { Appeal } \\
\text { dismissed }\end{array}$ \\
\hline 3. & $\begin{array}{c}A-G v \\
\text { Fardon } \\
\text { [2003] QSC } \\
331\end{array}$ & $\begin{array}{c}2 \\
\text { Oct } \\
2003\end{array}$ & $\begin{array}{l}\text { Originating } \\
\text { application }\end{array}$ & Atkinson $\mathrm{J}$ & $\begin{array}{l}\text { Dr Larder, } \\
\text { Dr Moyle }\end{array}$ & $\begin{array}{c}\text { Interim } \\
\text { detention order } \\
\text { granted }\end{array}$ \\
\hline 4. & $\begin{array}{l}\text { Attorney- } \\
\text { General v } \\
\text { Fardon } \\
\text { [2003] QSC } \\
379 \\
\end{array}$ & $\begin{array}{c}30 \\
\text { Oct } \\
2003\end{array}$ & $\begin{array}{l}\text { Determination } \\
\text { of final orders }\end{array}$ & White J & $\begin{array}{l}\text { As for \#3, plus: } \\
\text { Prof James, } \\
\text { Dr Boettcher, } \\
\text { Prof. Ogloff }\end{array}$ & $\begin{array}{l}\text { Detention order } \\
\text { granted }\end{array}$ \\
\hline 5. & $\begin{array}{c}A-G v \\
\text { Watego } \\
{[2003] \text { QSC }} \\
367\end{array}$ & $\begin{array}{c}31 \\
\text { Oct } \\
2003\end{array}$ & $\begin{array}{l}\text { Originating } \\
\text { application }\end{array}$ & Muir J & Dr Kar & $\begin{array}{l}\text { Application } \\
\text { dismissed }\end{array}$ \\
\hline 6. & $\begin{array}{c}A-G v \text { Nash } \\
{[2003] \text { QSC }} \\
377\end{array}$ & $\begin{array}{c}5 \\
\text { Nov } \\
2003 \\
\end{array}$ & $\begin{array}{l}\text { Originating } \\
\text { application }\end{array}$ & $\begin{array}{c}\text { P D } \\
\text { McMurdo J }\end{array}$ & N/A & $\begin{array}{l}\text { Application } \\
\text { dismissed }\end{array}$ \\
\hline 7. & $\begin{array}{c}\text { A-G Qld v } \\
\text { Watego } \\
\text { [2003] QCA } \\
512 \\
\end{array}$ & $\begin{array}{c}17 \\
\text { Nov } \\
2003\end{array}$ & $\begin{array}{c}\text { Appeal against } \\
\text { dismissal of } \\
\text { originating } \\
\text { application } \\
\end{array}$ & $\begin{array}{c}\text { McPherson, } \\
\text { Davies JJA } \\
\text { and Mullins } \\
\mathrm{J} \\
\end{array}$ & N/A & $\begin{array}{l}\text { Appeal } \\
\text { dismissed }\end{array}$ \\
\hline 8. & $\begin{array}{c}\text { Welford, } \\
\text { Attorney- } \\
\text { General } v \\
\text { Francis } \\
\text { [2004] QSC } \\
128\end{array}$ & $\begin{array}{c}5 \\
\text { May } \\
2004\end{array}$ & $\begin{array}{l}\text { Originating } \\
\text { application }\end{array}$ & Mackenzie J & Dr Moyle & $\begin{array}{c}\text { Final } \\
\text { determination } \\
\text { adjourned }\end{array}$ \\
\hline 9. & $\begin{array}{c}\text { Attorney- } \\
\text { General v W } \\
\text { [2004] QSC } \\
262\end{array}$ & $\begin{array}{c}10 \\
\text { Aug } \\
2004\end{array}$ & $\begin{array}{l}\text { Originating } \\
\text { application }\end{array}$ & Douglas J & Prof James & $\begin{array}{c}\text { Risk } \\
\text { assessment and } \\
\text { interim } \\
\text { detention orders } \\
\text { granted } \\
\end{array}$ \\
\hline 10. & $\begin{array}{l}R J \text { Welford, } \\
\text { A-G for the } \\
\text { State of Qld } \\
v \text { Francis } \\
{[2004]} \\
\text { QSC } 233\end{array}$ & $\begin{array}{c}13 \\
\text { Aug } \\
2004\end{array}$ & $\begin{array}{l}\text { Determination } \\
\text { of final orders }\end{array}$ & Byrne J & $\begin{array}{l}\text { Prof Nurcombe, } \\
\text { Dr Lawrence }\end{array}$ & $\begin{array}{l}\text { Detention order } \\
\text { granted }\end{array}$ \\
\hline
\end{tabular}




\begin{tabular}{|c|c|c|c|c|c|c|}
\hline 11. & $\begin{array}{c}\text { Attorney- } \\
\text { General for } \\
\text { the State of } \\
\text { Queensland } \\
v \text { Foy [2004] } \\
\text { QSC } 428\end{array}$ & $\begin{array}{c}30 \\
\text { Nov } \\
2004\end{array}$ & $\begin{array}{l}\text { Originating } \\
\text { application }\end{array}$ & Fryberg J & $\begin{array}{l}\text { Prof Nurcombe, } \\
\text { Dr Lawrence }\end{array}$ & $\begin{array}{l}\text { Adjournment } \\
\text { granted and } \\
\text { application for } \\
\text { interim } \\
\text { detention order } \\
\text { dismissed }\end{array}$ \\
\hline 12. & $\begin{array}{c}\text { Attorney- } \\
\text { General for } \\
\text { the State of } \\
\text { Queensland } \\
v G \text { QSC } \\
{[2004] 442}\end{array}$ & $\begin{array}{c}9 \\
\text { Dec } \\
2004\end{array}$ & $\begin{array}{l}\text { Originating } \\
\text { application }\end{array}$ & Fryberg J & $\begin{array}{c}\text { N/A (The } \\
\text { applicant relied } \\
\text { on evidence } \\
\text { from } \\
\text { psychologist } \\
\text { Mrs Rowland) }\end{array}$ & $\begin{array}{l}\text { Application for } \\
\text { interim } \\
\text { detention order } \\
\text { dismissed }\end{array}$ \\
\hline 13. & $\begin{array}{c}\text { Attorney- } \\
\text { General v } \\
\text { Foy [2005] } \\
\text { QSC 001 }\end{array}$ & $\begin{array}{c}6 \\
\text { Jan } \\
2005\end{array}$ & $\begin{array}{l}\text { Determination } \\
\text { of final orders }\end{array}$ & Douglas J & $\begin{array}{l}\text { As for \#11, } \\
\text { plus: Dr Moyle }\end{array}$ & $\begin{array}{l}\text { Supervision } \\
\text { order granted }\end{array}$ \\
\hline 14. & $\begin{array}{c}\text { Rodney John } \\
\text { Welford, } \\
\text { Attorney- } \\
\text { General for } \\
\text { the State of } \\
\text { Queensland } \\
\text { v Downs } \\
\text { [2005] QSC } \\
016 \\
\end{array}$ & $\begin{array}{c}10 \\
\text { Feb } \\
2005\end{array}$ & $\begin{array}{l}\text { Determination } \\
\text { of final orders }\end{array}$ & Byrne J & $\begin{array}{l}\text { Prof Nurcombe, } \\
\text { Dr Lawrence } \\
\text { Dr Colls }\end{array}$ & $\begin{array}{l}\text { Supervision } \\
\text { order granted }\end{array}$ \\
\hline 15. & $\begin{array}{c}\text { Attorney- } \\
\text { General } \\
\text { (Qld) } v \\
\text { Pearce }\end{array}$ & $\begin{array}{c}10 \\
\text { Mar } \\
2005\end{array}$ & $\begin{array}{l}\text { Originating } \\
\text { application }\end{array}$ & de Jersey CJ & $\begin{array}{c}\text { N/A (The } \\
\text { applicant relied } \\
\text { on evidence } \\
\text { from } \\
\text { psychologist } \\
\text { Ms Smith) } \\
\end{array}$ & $\begin{array}{c}\text { Risk } \\
\text { assessment } \\
\text { order granted }\end{array}$ \\
\hline 16. & $\begin{array}{c}\text { Attorney- } \\
\text { General v G } \\
\text { [2005] QSC } \\
071\end{array}$ & $\begin{array}{c}31 \\
\text { Mar } \\
2005\end{array}$ & $\begin{array}{l}\text { Determination } \\
\text { of final orders }\end{array}$ & McMurdo J & $\begin{array}{c}\text { Dr Moyle, } \\
\text { Dr Lawrence }\end{array}$ & $\begin{array}{l}\text { Supervision } \\
\text { order granted }\end{array}$ \\
\hline 17. & $\begin{array}{c}\text { Attorney- } \\
\text { General for } \\
\text { the State of } \\
\text { Queensland } \\
v \text { Fardon } \\
{[2005] \text { QSC }} \\
137\end{array}$ & $\begin{array}{c}11 \\
\text { May } \\
2005\end{array}$ & $\begin{array}{l}\text { Annual review } \\
\text { of detention } \\
\text { order }\end{array}$ & Moynihan J & $\begin{array}{l}\text { Dr Moyle, } \\
\text { Prof James }\end{array}$ & $\begin{array}{l}\text { Detention order } \\
\text { renewed }\end{array}$ \\
\hline 18. & $\begin{array}{c}\text { Attorney- } \\
\text { General for } \\
\text { the State of } \\
\text { Queensland } \\
\text { v Pearce } \\
{[2005] \text { QSC }} \\
314\end{array}$ & $\begin{array}{c}16 \\
\text { Aug } \\
2005\end{array}$ & $\begin{array}{l}\text { Determination } \\
\text { of final orders }\end{array}$ & Atkinson J & $\begin{array}{c}\text { Dr Lawrence, } \\
\text { Dr Moyle, } \\
\text { Dr Colls }\end{array}$ & $\begin{array}{l}\text { Detention order } \\
\text { granted }\end{array}$ \\
\hline 19. & $\begin{array}{c}\text { Attorney- } \\
\text { General v } \\
\text { Francis } \\
\text { [2005] QSC } \\
381\end{array}$ & $\begin{array}{c}21 \\
\text { Dec } \\
2005\end{array}$ & $\begin{array}{l}\text { Annual review } \\
\text { of detention } \\
\text { order }\end{array}$ & Mackenzie J & $\begin{array}{l}\text { Prof Nurcombe, } \\
\text { Dr Moyle }\end{array}$ & $\begin{array}{l}\text { Detention order } \\
\text { renewed }\end{array}$ \\
\hline
\end{tabular}




\begin{tabular}{|c|c|c|c|c|c|c|}
\hline 20 . & $\begin{array}{c}\text { Robert John } \\
\text { Fardon v } \\
\text { Attorney- } \\
\text { General for } \\
\text { the State of } \\
\text { Queensland } \\
\text { and Anor } \\
\text { [2006] QSC } \\
005\end{array}$ & $\begin{array}{c}27 \\
\text { Jan } \\
2006\end{array}$ & $\begin{array}{l}\text { Application for } \\
\text { declarations and } \\
\text { rescinding of } \\
\text { detention order }\end{array}$ & Philippides J & N/A & $\begin{array}{l}\text { Application } \\
\text { dismissed }\end{array}$ \\
\hline 21. & $\begin{array}{c}\text { Attorney- } \\
\text { General for } \\
\text { the State of } \\
\text { Queensland } \\
v \text { LBM } \\
{[2006] \text { QSC }} \\
33\end{array}$ & $\begin{array}{c}6 \\
\text { Feb } \\
2006\end{array}$ & $\begin{array}{l}\text { Reasons for } \\
\text { adjournment } \\
\text { and interim } \\
\text { order }\end{array}$ & Jones J & Unnamed & $\begin{array}{c}\text { Interim } \\
\text { detention order }\end{array}$ \\
\hline 22. & $\begin{array}{c}\text { Attorney- } \\
\text { General v } \\
\text { Van Dessel } \\
{[2006] \text { QSC }} \\
016\end{array}$ & $\begin{array}{c}10 \\
\text { Feb } \\
2006\end{array}$ & $\begin{array}{l}\text { Determination } \\
\text { of final orders }\end{array}$ & White J & $\begin{array}{l}\text { Dr Moyle, } \\
\text { Dr Grant, } \\
\text { Prof Nurcombe }\end{array}$ & $\begin{array}{l}\text { Supervision } \\
\text { order granted }\end{array}$ \\
\hline 23. & $\begin{array}{c}\text { Attorney- } \\
\text { General v } \\
\text { Hansen } \\
\text { [2006] QSC } \\
35\end{array}$ & $\begin{array}{c}6 \\
\text { Mar } \\
2006\end{array}$ & $\begin{array}{l}\text { Determination } \\
\text { of final orders }\end{array}$ & Mackenzie J & $\begin{array}{c}\text { Prof James, } \\
\text { Dr Lawrence, } \\
\text { Prof Nurcombe }\end{array}$ & $\begin{array}{l}\text { Supervision } \\
\text { order granted }\end{array}$ \\
\hline 24. & $\begin{array}{c}\text { The Director } \\
\text { of Public } \\
\text { Prosecutions } \\
v \text { Foy }[2006] \\
\text { QSC } 045\end{array}$ & $\begin{array}{c}13 \\
\text { Mar } \\
2006\end{array}$ & $\begin{array}{l}\text { Application for } \\
\text { revocation of } \\
\text { bail }\end{array}$ & Mackenzie J & N/A & $\begin{array}{c}\text { Application } \\
\text { dismissed }\end{array}$ \\
\hline 25. & $\begin{array}{c}\text { Attorney- } \\
\text { General } \\
\text { (Qld) v Yeo } \\
\text { [2006] QSC } \\
063\end{array}$ & $\begin{array}{c}3 \\
\text { Apr } \\
2006\end{array}$ & $\begin{array}{l}\text { Determination } \\
\text { of final orders }\end{array}$ & Philippides J & $\begin{array}{c}\text { Dr Moyle, } \\
\text { Dr Lawrence }\end{array}$ & $\begin{array}{l}\text { Detention order } \\
\text { granted }\end{array}$ \\
\hline 26. & $\begin{array}{c}\text { Attorney- } \\
\text { General for } \\
\text { the State of } \\
\text { Queensland } \\
v \text { Twigge } \\
{[2006] \text { QSC }} \\
107\end{array}$ & $\begin{array}{c}17 \\
\text { May } \\
2006\end{array}$ & $\begin{array}{l}\text { Determination } \\
\text { of final orders }\end{array}$ & Mullins J & $\begin{array}{c}\text { Dr Moyle, } \\
\text { Dr Grant }\end{array}$ & $\begin{array}{l}\text { Supervision } \\
\text { order granted }\end{array}$ \\
\hline 27. & $\begin{array}{c}\text { Attorney- } \\
\text { General for } \\
\text { the State of } \\
\text { Queensland } \\
\text { v McLean } \\
\text { [2006] QSC } \\
137\end{array}$ & $\begin{array}{c}17 \\
\text { May } \\
2006\end{array}$ & $\begin{array}{l}\text { Determination } \\
\text { of final orders }\end{array}$ & Dutney J & $\begin{array}{l}\text { Prof James, } \\
\text { Dr Lawrence, } \\
\text { Prof Nurcombe }\end{array}$ & $\begin{array}{c}\text { Supervision } \\
\text { order granted }\end{array}$ \\
\hline 28. & $\begin{array}{c}\text { Attorney- } \\
\text { General for } \\
\text { the State of } \\
\text { Queensland } \\
\text { v Bickle } \\
{[2006] \text { QSC }} \\
130\end{array}$ & $\begin{array}{c}2 \\
\text { June } \\
2006\end{array}$ & $\begin{array}{l}\text { Determination } \\
\text { of final orders }\end{array}$ & Moynihan J & $\begin{array}{l}\text { Prof Nurcombe, } \\
\text { Dr Grant, } \\
\text { Dr Whitefoot }\end{array}$ & $\begin{array}{c}\text { Supervision } \\
\text { order granted }\end{array}$ \\
\hline
\end{tabular}




\begin{tabular}{|c|c|c|c|c|c|c|}
\hline 29. & $\begin{array}{c}\text { Attorney } \\
\text { General for } \\
\text { the State of } \\
\text { Queensland } \\
v \text { Friend } \\
{[2006] \text { QSC }} \\
131\end{array}$ & $\begin{array}{c}2 \\
\text { June } \\
2006\end{array}$ & $\begin{array}{l}\text { Determination } \\
\text { of final orders }\end{array}$ & Moynihan J & Unnamed & $\begin{array}{l}\text { Supervision } \\
\text { order granted }\end{array}$ \\
\hline 30. & $\begin{array}{c}\text { Attorney- } \\
\text { General v } \\
\text { Foy [2006] } \\
\text { QSC 143 }\end{array}$ & $\begin{array}{c}14 \\
\text { June } \\
2006\end{array}$ & $\begin{array}{l}\text { Application for } \\
\text { rescinding of } \\
\text { supervision } \\
\text { order; or, } \\
\text { amendment of } \\
\text { supervision } \\
\text { order } \\
\end{array}$ & McMurdo J & $\begin{array}{l}\text { Dr Lawrence, } \\
\text { Prof Nurcombe }\end{array}$ & $\begin{array}{c}\text { Supervision } \\
\text { order amended }\end{array}$ \\
\hline 31. & $\begin{array}{c}\text { Attorney- } \\
\text { General for } \\
\text { the State of } \\
\text { Queensland } \\
v \text { Waghorn } \\
{[2006] \text { QSC }} \\
171\end{array}$ & $\begin{array}{c}14 \\
\text { July } \\
2006\end{array}$ & $\begin{array}{l}\text { Determination } \\
\text { of final orders }\end{array}$ & McMurdo J & $\begin{array}{l}\text { Dr Lawrence, } \\
\text { Dr Moyle, } \\
\text { Prof Whitford }\end{array}$ & $\begin{array}{l}\text { Detention order } \\
\text { granted }\end{array}$ \\
\hline 32. & $\begin{array}{c}\text { Attorney- } \\
\text { General } \\
\text { (Qld) v Van } \\
\text { Dessel } \\
\text { [2006] QCA } \\
\text { 285 }\end{array}$ & $\begin{array}{c}4 \\
\text { Aug } \\
2006\end{array}$ & $\begin{array}{l}\text { Appeal against } \\
\text { indefinite term } \\
\text { of supervision } \\
\text { order }\end{array}$ & $\begin{array}{c}\text { Jerrard, } \\
\text { Holmes JJA } \\
\text { and } \\
\text { MacKenzie J }\end{array}$ & N/A & Appeal allowed \\
\hline 33. & $\begin{array}{c}\text { Attorney- } \\
\text { General for } \\
\text { the State of } \\
\text { Queensland } \\
\text { v O'Rourke } \\
\text { [2006] QSC } \\
196\end{array}$ & $\begin{array}{c}14 \\
\text { Aug } \\
2006\end{array}$ & $\begin{array}{l}\text { Determination } \\
\text { of final orders }\end{array}$ & $\begin{array}{c}\text { Chesterman } \\
\mathrm{J}\end{array}$ & $\begin{array}{l}\text { Dr Lawrence, } \\
\text { Prof James, } \\
\text { Prof Nurcombe }\end{array}$ & $\begin{array}{l}\text { Supervision } \\
\text { order granted }\end{array}$ \\
\hline 34. & $\begin{array}{c}\text { Attorney- } \\
\text { General for } \\
\text { the State of } \\
\text { Queensland } \\
\text { v B [2006] } \\
\text { QSC } 227\end{array}$ & $\begin{array}{c}28 \\
\text { Aug } \\
2006\end{array}$ & $\begin{array}{l}\text { Determination } \\
\text { of final orders }\end{array}$ & Lyons J & $\begin{array}{c}\text { Dr Grant, } \\
\text { Dr Lawrence }\end{array}$ & $\begin{array}{l}\text { Supervision } \\
\text { order granted }\end{array}$ \\
\hline 35. & $\begin{array}{c}\text { Attorney- } \\
\text { General } \\
(Q L D) v F \\
{[2006] \text { QCA }} \\
324\end{array}$ & $\begin{array}{c}30 \\
\text { Aug } \\
2006\end{array}$ & $\begin{array}{l}\text { Appeal against } \\
\text { renewal of } \\
\text { detention order }\end{array}$ & $\begin{array}{l}\text { Keane and } \\
\text { Holmes JJA, } \\
\text { and Dutney J }\end{array}$ & N/A & $\begin{array}{c}\text { Appeal allowed } \\
\text { and supervision } \\
\text { order granted }\end{array}$ \\
\hline 36. & $\begin{array}{c}A-G(Q l d) v \\
\text { Francis } \\
\text { [2006] QCA } \\
372\end{array}$ & $\begin{array}{c}26 \\
\text { Sep } \\
2006\end{array}$ & $\begin{array}{l}\text { Further reasons } \\
\text { for allowance } \\
\text { of appeal }\end{array}$ & $\begin{array}{c}\text { Keane, } \\
\text { Holmes JJA } \\
\text { and Dutney J }\end{array}$ & N/A & $\begin{array}{c}\text { Supervision } \\
\text { order confirmed } \\
\text { and amended }\end{array}$ \\
\hline 37. & $\begin{array}{c}\text { Attorney- } \\
\text { General for } \\
\text { the State Of } \\
\text { Queensland } \\
v \text { Sutherland } \\
\text { [2006] QSC } \\
268 \\
\end{array}$ & $\begin{array}{c}27 \\
\text { Sep } \\
2006\end{array}$ & $\begin{array}{l}\text { Determination } \\
\text { of final orders }\end{array}$ & McMurdo J & $\begin{array}{c}\text { Dr Lawrence, } \\
\text { Dr Beech, } \\
\text { Prof James }\end{array}$ & $\begin{array}{l}\text { Supervision } \\
\text { order granted }\end{array}$ \\
\hline
\end{tabular}




\begin{tabular}{|c|c|c|c|c|c|c|}
\hline 38. & $\begin{array}{c}\text { Attorney- } \\
\text { General for } \\
\text { the State of } \\
\text { Queensland } \\
\text { v Fardon } \\
{[2006] \text { QSC }} \\
275 \\
\end{array}$ & $\begin{array}{c}27 \\
\text { Sep } \\
2006\end{array}$ & $\begin{array}{c}\text { Annual review } \\
\text { of detention } \\
\text { order }\end{array}$ & Lyons J & $\begin{array}{l}\text { Dr Grant, } \\
\text { Dr Moyle, } \\
\text { Dr Nielssen }\end{array}$ & $\begin{array}{c}\text { Final } \\
\text { determination } \\
\text { adjourned }\end{array}$ \\
\hline 39. & $\begin{array}{c}\text { Attorney- } \\
\text { General for } \\
\text { the State of } \\
\text { Queensland } \\
v \text { Toms } \\
{[2006] \text { QSC }} \\
298 \\
\end{array}$ & $\begin{array}{c}20 \\
\text { Oct } \\
2006\end{array}$ & $\begin{array}{l}\text { Determination } \\
\text { of final orders }\end{array}$ & $\begin{array}{c}\text { Chesterman } \\
\text { J }\end{array}$ & $\begin{array}{c}\text { Dr Lawrence, } \\
\text { Dr Grant }\end{array}$ & $\begin{array}{l}\text { Supervision } \\
\text { order granted }\end{array}$ \\
\hline 40. & $\begin{array}{c}\text { Attorney- } \\
\text { General } \\
\text { (Qld) v. } \\
\text { Beattie } \\
\text { [2006] QSC } \\
322\end{array}$ & $\begin{array}{c}26 \\
\text { Oct } \\
2006\end{array}$ & $\begin{array}{l}\text { Determination } \\
\text { of final orders }\end{array}$ & Helman J & $\begin{array}{l}\text { Prof James, } \\
\text { Dr Colls, } \\
\text { Prof Nurcombe }\end{array}$ & $\begin{array}{c}\text { Final } \\
\text { determination } \\
\text { adjourned }\end{array}$ \\
\hline 41. & $\begin{array}{c}A-G(\text { Qld }) v \\
\text { Francis } \\
\text { [2006] QCA } \\
425\end{array}$ & $\begin{array}{c}27 \\
\text { Oct } \\
2006\end{array}$ & $\begin{array}{l}\text { Application for } \\
\text { costs order }\end{array}$ & $\begin{array}{c}\text { Keane, } \\
\text { Holmes JJA } \\
\text { and Dutney J }\end{array}$ & N/A & $\begin{array}{c}\text { Application } \\
\text { denied }\end{array}$ \\
\hline 42. & $\begin{array}{c}\text { Attorney- } \\
\text { General for } \\
\text { the State of } \\
\text { Queensland } \\
v \text { Robinson } \\
\text { [2006] QSC } \\
328\end{array}$ & $\begin{array}{c}1 \\
\text { Nov } \\
2006\end{array}$ & $\begin{array}{l}\text { Determination } \\
\text { of final orders }\end{array}$ & Lyons J & $\begin{array}{c}\text { Dr Grant, } \\
\text { Prof James, } \\
\text { Dr Kar }\end{array}$ & $\begin{array}{l}\text { Detention order } \\
\text { granted }\end{array}$ \\
\hline 43. & $\begin{array}{c}\text { Attorney- } \\
\text { General for } \\
\text { the State of } \\
\text { Qld v B } \\
\text { [2006] QSC } \\
330\end{array}$ & $\begin{array}{c}3 \\
\text { Nov } \\
2006\end{array}$ & $\begin{array}{l}\text { Originating } \\
\text { application }\end{array}$ & Douglas J & $\begin{array}{l}\text { Dr Grant, } \\
\text { Dr Moyle }\end{array}$ & $\begin{array}{c}\text { Interim } \\
\text { supervision } \\
\text { order granted }\end{array}$ \\
\hline 44. & $\begin{array}{c}\text { Attorney- } \\
\text { General for } \\
\text { the State of } \\
\text { Queensland } \\
\text { v Fardon } \\
\text { [2006] QSC } \\
336\end{array}$ & $\begin{array}{c}8 \\
\text { Nov } \\
2006\end{array}$ & $\begin{array}{c}\text { Final } \\
\text { determination } \\
\text { of annual } \\
\text { review of } \\
\text { detention order }\end{array}$ & Lyons J & N/A & $\begin{array}{l}\text { Detention order } \\
\text { rescinded and } \\
\text { supervision } \\
\text { order granted }\end{array}$ \\
\hline 45. & $\begin{array}{c}A-G(\text { Qld }) v \\
\text { Fardon } \\
{[2006] \text { QCA }} \\
512\end{array}$ & $\begin{array}{c}4 \\
\text { Dec } \\
2006\end{array}$ & $\begin{array}{l}\text { Appeal against } \\
\text { rescinding of } \\
\text { detention order } \\
\text { and granting of } \\
\text { supervision } \\
\text { order }\end{array}$ & $\begin{array}{l}\text { McMurdo P, } \\
\text { Williams JA } \\
\text { and White J }\end{array}$ & N/A & $\begin{array}{c}\text { Appeal } \\
\text { dismissed }\end{array}$ \\
\hline 46. & $\begin{array}{c}A-G v \text { Wright } \\
\text { [2006] QSC } \\
389\end{array}$ & $\begin{array}{c}15 \\
\text { Dec } \\
2006\end{array}$ & $\begin{array}{l}\text { Determination } \\
\text { of final orders }\end{array}$ & Skoien AJ & $\begin{array}{c}\text { Prof James, } \\
\text { Prof Nurcombe, } \\
\text { Dr Colls }\end{array}$ & $\begin{array}{l}\text { Supervision } \\
\text { order granted }\end{array}$ \\
\hline
\end{tabular}




\begin{tabular}{|c|c|c|c|c|c|c|}
\hline 47. & $\begin{array}{c}\text { Attorney- } \\
\text { General for } \\
\text { the State of } \\
\text { Queensland } \\
v \text { Murry } \\
\text { [2007] QSC } \\
036\end{array}$ & $\begin{array}{c}5 \\
\text { Feb } \\
2007\end{array}$ & $\begin{array}{l}\text { Originating } \\
\text { application }\end{array}$ & White J & Prof James & $\begin{array}{l}\text { Unspecified } \\
\text { interim order } \\
\text { granted }\end{array}$ \\
\hline 48. & $\begin{array}{c}\text { Attorney- } \\
\text { General for } \\
\text { the State of } \\
\text { Queensland } \\
v \text { HTR } \\
\text { [2007] QSC } \\
019\end{array}$ & $\begin{array}{c}9 \\
\text { Feb } \\
2007\end{array}$ & $\begin{array}{l}\text { Determination } \\
\text { of final orders }\end{array}$ & Lyons J & $\begin{array}{l}\text { Prof Nurcombe, } \\
\text { Dr Beech }\end{array}$ & $\begin{array}{l}\text { Supervision } \\
\text { order granted }\end{array}$ \\
\hline 49. & $\begin{array}{c}\text { A-G for the } \\
\text { State of Qld } \\
v \text { Ward } \\
{[2007] \text { QSC }} \\
033\end{array}$ & $\begin{array}{c}21 \\
\text { Feb } \\
2007\end{array}$ & $\begin{array}{l}\text { Determination } \\
\text { of final orders }\end{array}$ & Muir J & $\begin{array}{c}\text { Dr Beech, } \\
\text { Dr Moyle, } \\
\text { Prof Nurcombe }\end{array}$ & $\begin{array}{l}\text { Supervision } \\
\text { order granted }\end{array}$ \\
\hline 50. & $\begin{array}{c}\text { Attorney- } \\
\text { General for } \\
\text { the State of } \\
\text { Queensland } \\
v \text { Reynolds } \\
\text { [2007] QSC } \\
52 \\
\end{array}$ & $\begin{array}{c}13 \\
\text { Mar } \\
2007\end{array}$ & $\begin{array}{l}\text { Determination } \\
\text { of final orders }\end{array}$ & Mullins J & $\begin{array}{l}\text { Prof James, } \\
\text { Prof Nurcombe, } \\
\text { Dr Lawence }\end{array}$ & $\begin{array}{l}\text { Supervision } \\
\text { order granted }\end{array}$ \\
\hline 51. & $\begin{array}{c}A-G(\text { Qld }) v \\
\text { Beattie } \\
\text { [2007] QCA } \\
96\end{array}$ & $\begin{array}{c}30 \\
\text { Mar } \\
2007\end{array}$ & $\begin{array}{l}\text { Appeal against } \\
\text { detention order }\end{array}$ & $\begin{array}{c}\text { Keane and } \\
\text { Holmes JJA } \\
\text { and Douglas } \\
\mathrm{J}\end{array}$ & N/A & $\begin{array}{c}\text { Appeal } \\
\text { dismissed }\end{array}$ \\
\hline 52. & $\begin{array}{c}A-G(\text { Qld }) v \\
\text { Robinson } \\
\text { [2007] QCA } \\
111\end{array}$ & $\begin{array}{c}5 \\
\text { Apr } \\
2007\end{array}$ & $\begin{array}{l}\text { Appeal against } \\
\text { detention order }\end{array}$ & $\begin{array}{c}\text { Keane, } \\
\text { Holmes JJA } \\
\text { and Douglas } \\
\mathrm{J}\end{array}$ & N/A & $\begin{array}{c}\text { Appeal } \\
\text { dismissed }\end{array}$ \\
\hline 53. & $\begin{array}{c}\text { Attorney- } \\
\text { General for } \\
\text { the State of } \\
\text { Queensland } \\
v \text { Murry } \\
{[2007] \text { QSC }} \\
121\end{array}$ & $\begin{array}{c}28 \\
\text { May } \\
2007\end{array}$ & $\begin{array}{l}\text { Determination } \\
\text { of final orders }\end{array}$ & $\begin{array}{c}\text { Chesterman } \\
\mathrm{J}\end{array}$ & $\begin{array}{l}\text { Prof Nurcombe, } \\
\text { Dr Beech, } \\
\text { Prof James }\end{array}$ & $\begin{array}{l}\text { Supervision } \\
\text { order granted }\end{array}$ \\
\hline 54. & $\begin{array}{c}\text { Attorney- } \\
\text { General for } \\
\text { the State of } \\
\text { Queensland } \\
\text { v. Foy [2007] } \\
\text { QSC 141 }\end{array}$ & $\begin{array}{c}5 \\
\text { June } \\
2007\end{array}$ & $\begin{array}{l}\text { Application for } \\
\text { amendment of } \\
\text { supervision } \\
\text { order }\end{array}$ & Helman J & $\begin{array}{c}\text { Dr Wright } \\
\text { Dr Lawrence }\end{array}$ & $\begin{array}{c}\text { Final } \\
\text { determination } \\
\text { adjourned }\end{array}$ \\
\hline
\end{tabular}


